\title{
Therapeutics for Graft-versus-Host Disease: From Conventional Therapies to Novel Virotherapeutic Strategies
}

\author{
Nancy Y. Villa ${ }^{1}$, Masmudur M. Rahman ${ }^{2}$, Grant McFadden ${ }^{2, *}$ and Christopher R. Cogle ${ }^{1, *}$ \\ 1 Division of Hematology and Oncology, Department of Medicine, University of Florida, Gainesville, \\ FL 32610, USA; nancy.villa@medicine.ufl.edu \\ 2 Department of Molecular Genetics and Microbiology, University of Florida, Gainesville, FL 32610, USA; \\ masmudur@ufl.edu \\ * Correspondence: grantmcf@ufl.edu (G.M.); christopher.cogle@medicine.ufl.edu (C.R.C.); \\ Tel.: +1-352-273-6852 (G.M.); +1-352-273-7493 (C.R.C.)
}

Academic Editors: Martine L.M. Lamfers and E. Antonio Chiocca

Received: 28 December 2015; Accepted: 9 March 2016; Published: 22 March 2016

\begin{abstract}
Allogeneic hematopoietic stem cell transplantation (allo-HSCT) has a curative potential for many hematologic malignancies and blood diseases. However, the success of allo-HSCT is limited by graft-versus-host disease (GVHD), an immunological syndrome that involves inflammation and tissue damage mediated by donor lymphocytes. Despite immune suppression, GVHD is highly incident even after allo-HSCT using human leukocyte antigen (HLA)-matched donors. Therefore, alternative and more effective therapies are needed to prevent or control GVHD while preserving the beneficial graft-versus-cancer (GVC) effects against residual disease. Among novel therapeutics for GVHD, oncolytic viruses such as myxoma virus (MYXV) are receiving increased attention due to their dual role in controlling GVHD while preserving or augmenting GVC. This review focuses on the molecular basis of GVHD, as well as state-of-the-art advances in developing novel therapies to prevent or control GVHD while minimizing impact on GVC. Recent literature regarding conventional and the emerging therapies are summarized, with special emphasis on virotherapy to prevent GVHD. Recent advances using preclinical models with oncolytic viruses such as MYXV to ameliorate the deleterious consequences of GVHD, while maintaining or improving the anti-cancer benefits of GVC will be reviewed.
\end{abstract}

Keywords: cancer; hematopoietic cell transplant; allogeneic; allo-HSCT; GVHD; GVC; MYXV

\section{Introduction}

Allogeneic hematopoietic stem cell transplantation (allo-HSCT) involves the transfer of multipotent hematopoietic stem cells from a healthy donor to a genetically non-identical recipient [1]. Allo-HSCT is the most promising therapy used to treat high-risk hematologic malignancies as well as some benign disorders [2]. The major clinical advantage of allo-HSCT is the high degree of anti-cancer effect against residual disease in the transplant recipient following allo-HSCT, also known as graft-versus-cancer (GVC) [3], which is mediated by donor T cells and can exert potent anti-neoplastic effects [1]. However, the main clinical complication of allo-HSCT is the development of graft-versus-host disease (GVHD), an immunological disorder also mediated by donor T cells. Donor T cells can be very toxic to the recipient, even with close human leukocyte antigen (HLA) matching of the donor and patient. These donor $\mathrm{T}$ cells have the potential to attack and damage multiple organs and tissues of the allo-transplanted recipient, resulting in high risk for morbidity and mortality [4].

Despite the progress over the past several years regarding prophylaxis to better control GVHD, the need remains for more effective methods that guarantee not only the control and management 
of GVHD but also the maintenance, or even improvement, of GVC. Recently, virotherapeutics with oncolytic viruses or genetically modified viruses, have demonstrated potential to promote and improve the GVC effect. For example, myxoma virus (MYXV), a rabbit-specific virus that can mediate oncolysis in a wide spectrum of human cancers [5-11], has now emerged as a promising ex vivo agent to control GVHD and also augment the anti-cancer effects mediated by GVC $[12,13]$.

The pathophysiology of GVHD will be reviewed, focusing on the successes and failures of the associated research and the potential impact of GVHD on allo-HSCT in clinical practice. We also review the current, and most promising emerging therapies to prevent or control GVHD and to elaborate on the strengths and limitations of these strategies. Furthermore, the status of novel therapies to prevent, and control GVHD while preserving GVC will be summarized. Emphasis will be placed on the virotherapeutic strategy with MYXV, which appear to possess the dual consequences of controlling GVHD while at the same time augmenting the anti-cancer effects of GVC.

\section{Clinical and Biological Overview of Graft-versus-Host Disease}

\subsection{Allogeneic Hematopoietic Stem Cell Transplantation Is the Only Potential Cure for Many Blood-Related Diseases, However the Practice Is Limited by Graft-versus-Host Disease}

Allo-HSCT is the only curative therapy for many chemotherapy-refractory or relapsed hematologic malignancies [14]. The genesis of allo-HSCT dates back the early 1950s with rodent studies, demonstrating the potential of donated bone marrow to prevent radiation-mediated mortality, which was a great concern with the start of the nuclear age and the Cold War [15,16]. The discovery of human histocompatibility antigens along with the development of immunosuppressive drugs paved the way for the first successful allogeneic bone marrow transplant performed in 1968 [17]. Despite the impact of allo-HSCT, only $25 \%$ of patients have a major HLA-identical sibling, whereas a suitable HLA-compatible unrelated volunteer can be located for fewer than $70 \%$ of remaining patients [18]. Alternative donors including HLA-haploidentical relatives are now increasingly used [18].

\subsubsection{Sources of Hematopoietic Stem Cells Influence the Development of GVHD}

Several stem cell sources have been used for allo-HSCT. For instance, bone marrow (BM), a rich source of hematopoietic stem and progenitor cells (HSPCs), was the sole source of donor HSPCs until the 1990s (referred to as allogeneic bone marrow transplantation or allo-BMT). In the mid-1990s, donor peripheral blood (PB) that had been mobilized with the cytokines granulocyte colony-stimulating factor (G-CSF) or granulocyte macrophage colony-stimulating factor (GM-CSF) was increasingly used as a source of allo-HSCT [19]. The advantage of using mobilized PB for HSPCT include faster recovery of neutrophil and platelets [20]; however, a drawback of mobilized PB is a higher GVHD risk compared to BM. Umbilical cord blood (UCB) is another source of HSPCs [21]. Whereas UCB transplant is associated with lower risk for GVHD due to higher quantities of more naïve T lymphocytes, the low quantity of hematopoietic stem cells in the UCB unit limits its widespread applicability in engrafting within adults $[22,23]$.

\subsubsection{Conditioning, Graft Manipulation and Post-Transplant Procedures Affect the Success} of Allo-HSCT

Prior to allo-HSCT, patients receive conditioning regimens with chemotherapy and/or radiation in order to (a) kill residual cancer cells in the patient, and (b) inactivate the host immune system so that the allograft will not be rejected. Conditioning is followed by the intravenous infusion of donor HSPCs that seed donor-derived hematopoiesis [24]. In addition, donor-derived immune cells, particularly allo-reactive $\mathrm{T}$ lymphocytes, promote immune reactions that control and eradicate residual cancer cells that may have resisted the conditioning chemotherapy and/or radiation. This immunotherapeutic, anti-cancer effect following allo-HSCT is called graft-versus-cancer (GVC) and is one of the major therapeutic reasons for allo-HSCT in the treatment of hematological malignancies [25]. Unfortunately, 
the number of patients eligible for allo-HSCT is limited by the risks and detrimental effects of GVHD, which is a substantial cause of morbidity and mortality after the allo-HSCT. In fact, GVHD occurs in approximately $40 \%-60 \%$ of all allo-transplanted recipients [26] and results in death in up to $20 \%$ of these recipients $[1,27]$. The development and severity of GVHD in transplant recipients depends on recipient age, toxicity of conditioning regimen hematopoietic graft source and the nature of any GVHD prophylaxis.

Another obstacle of allo-HSCT is delayed immune reconstitution, which is exacerbated by the prolonged post-transplant immune suppression required to reduce the risk of GVHD. In this time of immunocompromise, recipients are at very high risk of developing opportunistic diseases like fungal infections, cytomegalovirus (CMV) reactivation, and post-transplant lymphoproliferative lymphomas. It should also be noted that during active GVHD, the patient is also at very high risk of opportunistic infections due to a lack of immunocompetency against microbial infections. Although the prevention and treatment of GVHD induce additional immunocompromise, GVHD itself is an immunopathological condition.

In order to increase the number of patients eligible for allo-transplantation, a balance between ameliorating GVHD and yet preserving GVC is required, as well as the implementation of parameters such as donor selection, stem cell source, conditioning, immune reconstitution, and immunosuppressive regimens [24]. These are the key challenges that need to be addressed in the field of allo-HSCT in order to improve clinical outcomes such as reduced GVHD, elimination of residual disease burden, and increased post-transplant survival times.

\subsection{Graft-versus-Host Disease: Pathogenesis}

Barnes and colleagues initially reported GVHD as a "secondary disease" developed in mice as a result of lethal irradiation and treatment with foreign bone marrow [28]. Later, Billingham defined three essential prerequisites for the development of GVHD: the presence of immunologically competent cells in the donor graft, histocompatibility difference between the donor and the recipient, and the inability of the immunosuppressed recipient to mount an effective immune response to reject the donor cells [1,29]. In 1978, Korngold and Sprent identified mature donor T cells as the fundamental cellular mediators of GVHD [30]. More recently, other factors such as host [31] and donor [32,33] antigen presenting cells (APCs) have also been recognized as crucial in the development GVHD. Today it is clear that the interaction between donor T cells with APCs in general is important for the induction of GVHD. Such interactions can be positively or negatively regulated by a myriad of cytokines, chemokines and other immune cell subsets [34]. Recent studies, however, have demonstrated that donor B cells can also contribute to the immunopathology of GVHD [35-37]; but the mechanism(s) by which B cells contribute to GVHD remain elusive.

The development of GVHD occurs in five steps, which are schematically represented in Figure 1. The first step involves tissue damage from pre-transplantation conditioning regimens including chemotherapy and/or radiotherapy [20]. The conditioning regimens result in the release inflammatory mediators including tumor necrosis factor (TNF), interleukin-1 (IL-1), adhesion molecules and other danger signals that promote enhancement of the expression of major histocompatibility complex (MHC) proteins [38], the activation and maturation of APCs [39,40], as well as the rapid amplification of donor $\mathrm{T}$ cells [41]. The second step corresponds to donor $\mathrm{T}$ cell activation and co-stimulation following the recognition and interaction of the T cell receptor (TCR) and the co-stimulatory molecule CD28 with their cognate ligands expressed on the surface of APCs [42]. The third step is the expansion and differentiation of alloreactive $\mathrm{T}$ cells into naïve, effector, memory, regulatory, $\mathrm{T}$ helper/ $\mathrm{T}$ cytotoxic cells such Th-1/Tc-1, Th2/Tc2, Th17 and other subsets. Step four is the trafficking of activated T cells to GVHD target tissues, and the further recruitment of other effector leukocytes [38]. Fifth, effector $\mathrm{T}$ cells produce toxic cytokines and other immune effectors that induce cell death in the infiltrated recipient tissues. For instance, cytotoxic T lymphocytes, $\mathrm{CD}^{+}$and $\mathrm{CD} 8^{+}$, are the major effectors of GVHD and cause tissue damage by a variety of pathways including: the Fas-Fas ligand (FasL) and 
perforin-granzyme pathways [43], TNF-receptor (TNFR)-like death receptors such as TNF-related apoptosis-inducing ligand (TRAIL) and TNF-like weak inducer of apoptosis (TWEAK) [44-48]. Tissue damage also leads to increased inflammatory signals, perpetuating and augmenting the disease process by contributing to the cytokine proliferation that fuels GVHD [42].

(1)

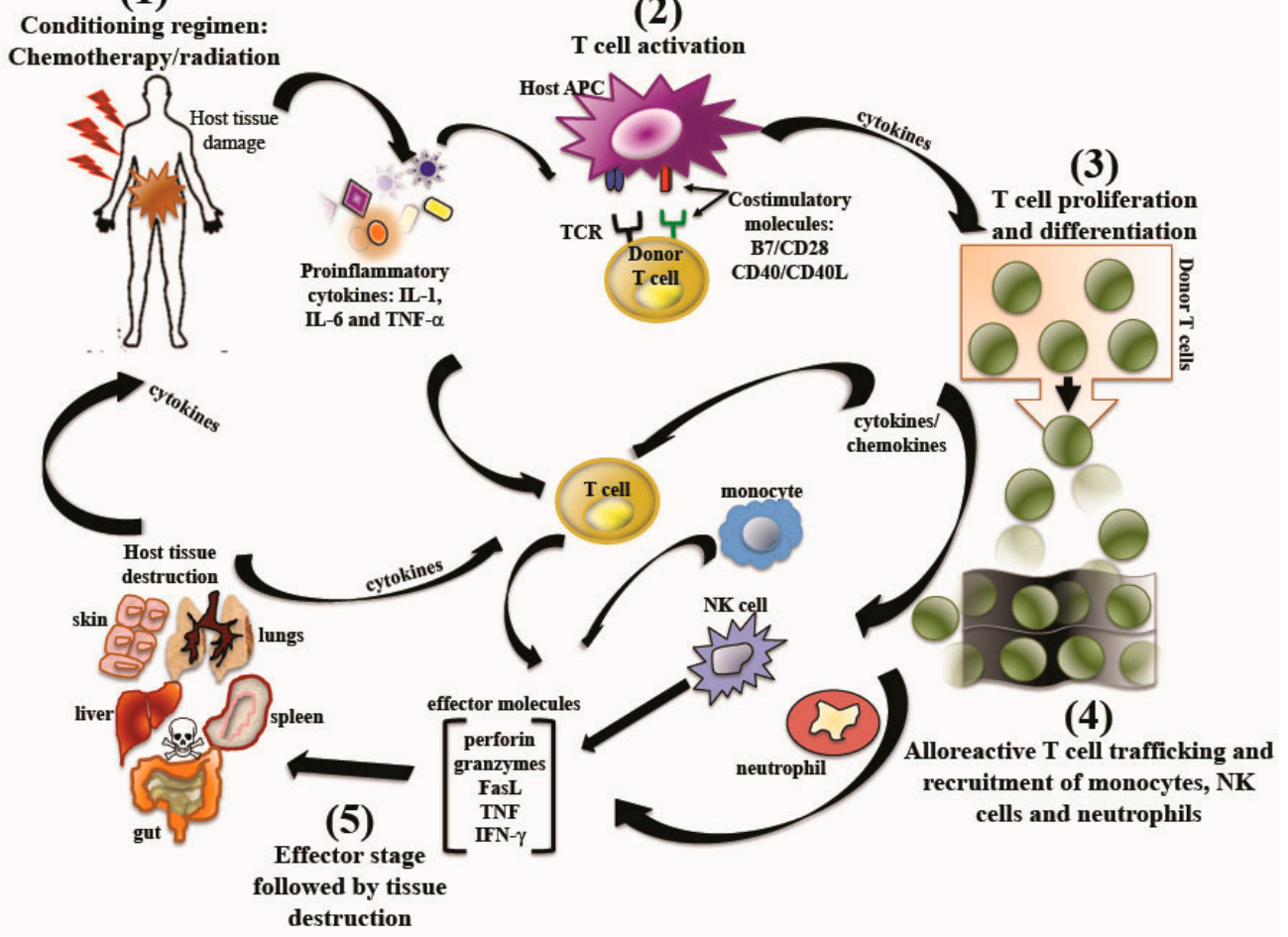

Figure 1. Overview of the pathophysiology of graft-versus-host disease. The pathophysiology of graft-versus-host disease (GVHD) involves five steps. (1) Conditioning regimen with chemotherapy and/or total body irradiation, which results in the release of pro-inflammatory cytokines that affects host-antigen presenting cells (APCs) by increasing their maturation and the expression of co-stimulatory molecules and cytokines, which in turn fuel donor alloreactive T cells. (2) T cell recognition followed by $\mathrm{T}$ cell receptor (TCR) ligation, (the first signal to the donor T cells) and engagement of stimulatory molecules (the second signal to the donor $\mathrm{T}$ cells). Both of these signals are required for full $\mathrm{T}$ cell activation and subsequent expansion. (3) Proliferation and differentiation of alloreactive donor T cells, followed by (4) trafficking of alloreactive T cells toward GVHD target organs (e.g., skin, gut, liver, lungs), a process that is controlled by chemokines and adhesion molecules. Inflamed and injured tissues produce chemokines, which also result in the recruitment of neutrophils, natural killer (NK) cells, and monocytes to GVHD organs and contribute to the GVHD pathology. (5) The effector phase notes for the destruction of host tissue by effector molecules such as Fas ligand (FasL), perforin, granzymes, interferon-gamma (IFN- $\gamma$ ), tumor necrosis factor (TNF), that induce a cytokine storm that drives the whole GVHD process.

Although APCs and T cells are commonly associated with the development of GVHD, recently, several studies have indicated that non-T cells like neutrophils can also be effectors of GVHD [49-51].

Neutrophils promote $\mathrm{T}$ cell activation by cleaving chemokines and producing reactive oxygen species (ROS) [52,53]. Thus, in the setting of an allo-HSCT, neutrophils amplify tissue damage caused by conditioning regimens [49]. In vivo studies using myeloperoxidase imaging showed that neutrophil infiltration $\left(\mathrm{Ly}_{6 \mathrm{G}}{ }^{+}\right.$) of mouse ileum after allo-HSCT was dependent of the microbial flora [49]. Neutrophil contribution to GVHD severity occurs via ROS production. Accordingly, deficiency of $C y b b$ (encoding cytochrome b-245, beta polypeptide, also known as NOX2) in neutrophils disabled ROS production and led to lower levels of tissue damage, GVHD-related mortality and 
effector phenotype T cells. In humans, severity of intestinal GVHD correlates with the levels of neutrophils in GVHD lesions [49]. The studies conducted by Schwab and co-workers demonstrated that neutrophils do not contribute directly to GVHD, yet induce tissue damage, which lead to T cell activation and the development of GVHD [49].

Prevention of neutrophil granulocyte infiltration and degranulation can minimize GVHD.

In this setting, Giroux and co-workers showed that SMAD3 had a role in preventing neutrophils infiltration through the suppression of T helper 1 (Th1) skewing of donor CD4+ T cells.

SMAD3 is a receptor that regulates transforming growth factor- $\beta$ (TGF- $\beta$ ) signals, [50]. TGF- $\beta$ signaling plays a key role self-tolerance via the regulation of lymphocyte proliferation differentiation and survival [54]. TGF- $\beta$ also controls inflammatory responses through the regulation of chemotaxis, activation and survival of lymphocytes, natural killer cells, dendritic cells, macrophages, mast cells and granulocytes [54].

The studies conducted by Giroux et al., demonstrated that the presence of SMAD3 was necessary to decrease the generation of monocytes, neutrophils, as well as the production of ROS by neutrophils. In contrast to wild type (WT), SMAD3- knockout (KO) grafts induced lethal GVHD in major histocompatibility complex-identical recipients. The severity of GVHD was associated with abundant leukocyte infiltration, mainly $\mathrm{T}$ cells $\left(\mathrm{CD} 4^{+}\right)$and neutrophils $\left(\mathrm{CD} 11 \mathrm{~b}^{+} \mathrm{Gr}-1^{+}\right)$into the intestine of recipients [50].

In 2004, a clinical study conducted in humans by Socié et al., demonstrated that increased transplant-related mortality (TRM) was correlated with the expression in situ of apoptosis mediators such as TNF- $\alpha$ and Fas in the gastrointestinal (GI) tract during digestive GVHD, as well as increased cellular infiltration of neutrophils in target organs after allo-HSCT [51]. Therefore, a deleterious role of neutrophils on human GVHD adds even more complexity to the pathogenesis of GVHD.

\subsection{Graft-versus-Host Disease: Clinical Presentations}

The clinical presentation of GVHD is heterogeneous, involving the skin, mucosa, GI track, liver and lungs [29]. Based on the time frame and type of pathological process, GVHD can be characterized as acute or chronic. Historically, acute GVHD (aGVHD) occurs within 100 days of HSCT, whereas chronic GVHD (cGVHD) occurs beyond 100 days of the HSCT. However, it is now accepted that clinical features of aGVHD and cGVHD may co-exist and that clinical features of cGVHD can even occur within 100 days after transplant [55]. In terms of mediated factors, it has been thought that aGVHD is driven by Th1-type and Th17-type immune responses, whereas cGVHD is predominantly driven by Th2-type responses. However, recent mouse and human studies have demonstrated that such paradigm is not absolute [20,56-60]. Therefore, a full understanding of the pathophysiology underlying aGVHD and cGVHD is still incomplete. However, it is clear that aGVHD and cGVHD involve distinct pathological processes. For instance, aGVHD has strong inflammatory components whereas CGVHD displays more autoimmune and fibrotic features [1]. There are several risk factors that favor the development of aGVHD or cGVHD. For instance, recipient HLA mismatching and the use of unrelated donors had a greater effect on the risk of aGVHD than on cGVHD. Additionally, total body irradiation was strongly associated with aGVHD. On the other hand, the use of female donors for male recipients correlates more with cGVHD. The use of mobilized blood grafts was associated with cGVHD. Older patients are more susceptible to cGVHD [61]. We next briefly summarize the pathophysiology of aGVHD and cGVHD.

\subsubsection{Acute Graft-versus Host Disease}

The incidence of aGVHD varies with incidence of grade II-IV GVHD at $40 \%$ in matched related donor (MRD) transplant to 50\% matched unrelated donor (MUD) transplant [2]. Acute GVHD primarily affects the recipient's skin, GI tract and the liver [34]. The immunobiology of aGVHD is very complex, involving a network of immune interactions where the key players are naïve $\mathrm{T}$ cells, host and donor APCs, regulatory T cells (Tregs), among others. The pathophysiology of aGVHD involves three 
steps: inflammation and tissue damage driven by pre-transplant conditioning regimens, activation and clonal expansion of donor T cells like Th1, accompanied with the secretion of inflammatory cytokines, and release of cellular and inflammatory factors culminating with tissues destruction [62-64]. The direct triggers for the induction of aGVHD include: disparities between histocompatibility antigens between recipient and donor, conditioning regimen that the recipient/patient received, and GVHD prevention regimen [34].

\section{HLA Disparity}

HLA disparity can be at the level of major or minor histocompatibility antigens, which are variable among individuals [65]. The incidence of aGVHD increases with the greater degree of HLA mismatch [66,67]. However, in HLA-matched siblings, mismatches in minor histocompatibility antigens also contribute to GVHD [68,69].

\section{Conditioning Regimens}

Pre-transplant conditioning regimens trigger the innate immune system with the concomitant induction of aGVHD. Chemo- and radio-therapeutic conditioning regimens performed prior the infusion of BMT donor cells induce the release of pathogen-associated molecular patterns (PAMPs), such as the endotoxin lipopolysacchraride (LPS). The interaction of LPS with toll-like receptors (TLRs) like TLR-4 initiates cellular signaling pathways that activate cytokine secretion [41], such as nuclear factor- $\mathrm{BB}(\mathrm{NF}-\kappa \mathrm{B})$ [70] and pro-inflammatory cytokines including IL-1, IL-6, TNF, and other IFN family members in a process described as a "cytokine storm" [40,41,71,72].

In aGVHD, the immune response is mounted when APCs sense endogenous molecules that are activated after the conditioning regimen-mediated tissue damage, like damage-associated molecular patterns (DAMPs), which present the MHC or minor histocompatibility antigen disparate protein, and provide secondary co-stimulatory signals via CD28, ICOS, CD40, CD30, 4-IBB and OXO40 molecules, and tertiary (cytokine) signals for activation of mediators of aGVHD such as different subsets of the allo-reactive T cells (mediators of aGVHD). The pivotal role of T cells in aGVHD is supported by the complete abrogation of GVHD following depletion of T cells from the allo-graft, an approach that remains the most effective in preventing aGVHD [1]. However, this strategy also compromises GVC.

As mentioned before, conditioning can induce tissue injury and cell death. Dying cells release adenosine $5^{\prime}$-triphosphate (ATP), which is not only a danger signal that triggers innate immune response pathways, but also is the main endogenous ligand of the P2X7 receptor (P2X7R). Activation of P2X7R is a critical step in the pathogenesis of GVHD [73]. In vitro and in vivo studies have demonstrated that stimulation of APCs with ATP leads to increase expression of CD80 and CD86 and induce a cascade of pro-inflammatory events such as the phosphorylation of signal transducer and activator of the transcription 1 (STAT1), production of IFN- $\gamma$ and donor T cell expansion, and the reduction of regulatory $\mathrm{T}$ cell numbers. Therefore, ATP neutralization, blockage or genetic deficiency of P2X7R during the development of GVHD can improve survival [73].

Furthermore, the interaction between ATP and P2X7R promotes assembly and activation of the Nod-like receptor protein 3 (Nlrp3) inflammasome, an intracellular multiprotein complex that controls the activation of inflammatory caspase- 1 in response to exogenous and endogenous stress or danger signals [74]. After conditioning regimen, intestinal commensal bacteria and the damage-associated molecular pattern uric acid contribute to Nlrp3 inflammasome-mediated IL- $1 \beta$ production, which affects GVHD in the early phase after allo-HCT. Thus, gastrointestinal decontamination and depletion of uric acid are alternatives to reduce the severity of GVHD. Moreover, early blockade or genetic deficiency of IL-1 $\beta$ receptor in dendritic cells (DCs) and T cells prolongs survival [75]. Nlrp3 and the apoptosis-associated spec-like protein ASC, two components of the Nlrp3 inflammasome mediate the cleavage of the precursor IL-1 $\beta$ protein (pro-IL-1 $\beta$ ) into its active form. Accordingly, Nlrp3 and ASC are critical for the full manifestation of GVHD. Increase levels of active caspase- 1 and IL-1 $\beta$ have 
been found in circulating leukocyte and in intestinal GVHD lesions of patients compared with patients without GVHD [75].

Co-stimulation signals are required to achieve $\mathrm{T}$ cell activation, proliferation, differentiation and survival [76]. In vivo studies have demonstrated that inhibition of co-stimulatory molecules reduces acute GVHD [34,77-79]. On the other hand, blockade of inhibitory signals, (for instance, those that inhibit the T cell response) such as programmed death-1 (PD-1) and cytotoxic T lymphocyte associated protein 4 (CTLA-4), exacerbates aGVHD in murine models [80].

As mentioned above, alloreactive donor $\mathrm{T}$ cells are the critical mediators of aGVHD. Alloreactive donor $\mathrm{T}$ cells consist of several subsets with different stimuli responsiveness, activation thresholds, and effector functions [34]. The composition of host allo-antigens dictates which donor lymphocyte subsets will differentiate and proliferate [4]. Mediators of aGVHD and their implications on the pathophysiology of aGVHD are summarized in Table 1.

Table 1. Mediators of acute graft-versus-host disease.

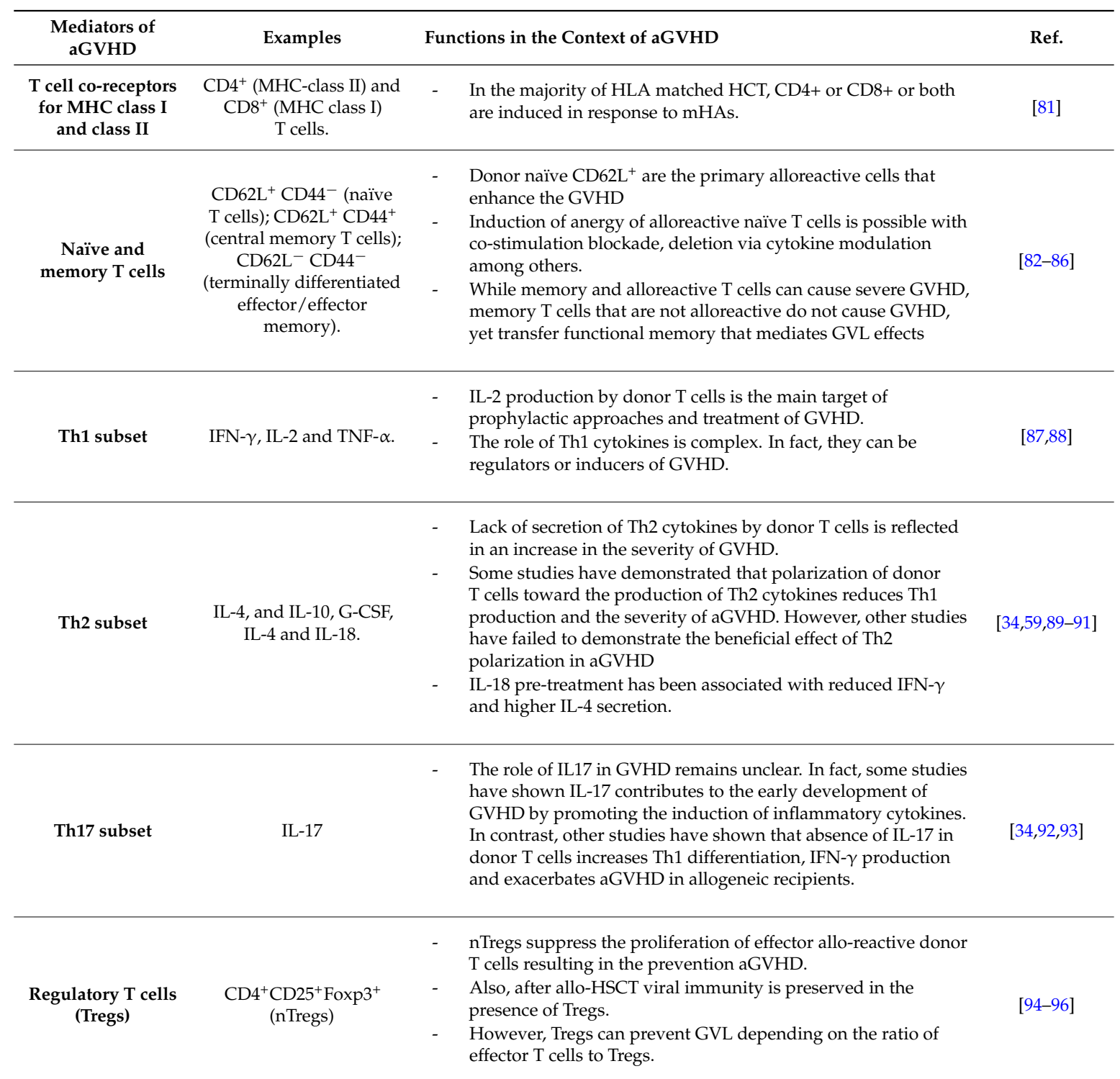

GVHD: graft-versus-host disease; aGVHD: acute graft-versus-host disease; allo-HSCT: allogeneic hematopoietic stem cell transplantation; G-CSF: granulocyte colony-stimulating factor; GVL: graft-versus-leukemia; IFN: interferon; HCT: hematopoietic cell transplant; HLA: human leukocyte antigen; MHC: major histocompatibility complex; mHa: minor histocompatibility antigen; IL: interleukin; Ref: reference; nTregs: naturally occurring Tregs. 


\subsubsection{Chronic Graft-versus-Host Disease}

cGVHD affects $30 \%-80 \%$ of patients receiving allo-HSCT [64] with a 5-year mortality rate of $30 \%-50 \%$, mainly due to immune regulation and opportunistic infections [1]. cGVHD is a multi-organ syndrome, with a clinical presentation resembling autoimmune vascular diseases, such as systemic lupus erythematosus, Sjögren's syndrome, lichen planus, and scleroderma [97]. The first symptoms of cGVHD tend can appear around 100 days after the allo-HSCT; however, cGVHD often presents clinically many months to years after transplant [61].

Classically, Th2 responses have been involved in the pathophysiology of cGVHD. However, we now recognize that the biology of cGVHD is much more complex and thus other factors such as thymic dysfunction, transforming growth factor- $\beta$ (TGF- $\beta$ ) and platelet-derived growth factor (PDGF), B cells and autoantibodies, and Th1/Th2/Th17 cytokines, as well as regulatory T cells (Tregs), need to be taken into consideration [98].

The treatment of cGVHD is based on its severity. For instance, mild cGVHD is treated with topical immunosuppressive agents or systemic steroids. Moderate to severe cGVHD requires treatment with systemic immunosuppression including prednisone with continued administration of calcineurin inhibitor for steroid sparing [99]. A major complication of cGVHD is a steroid-refractory state, which portends for a poor prognosis. Preclinical studies using mouse models demonstrated that the synthetic retinoid Am80 attenuated cGVHD by downregulating Th1 and Th17 differentiation in donor T cells $[97,98,100]$. More detailed research on the pathophysiology of cGVHD may help establish novel strategies for its prevention and treatment.

\section{Prevention of Graft-versus-Host Disease: Current Clinical Principles and Strategies}

Despite the progress in understanding the pathophysiology of GVHD, the limited success of established therapies for prevention and treatment of GVHD remains unsatisfactory. The ideal clinical scenario for allo-HSCT would be prevention of GVHD while retaining GVC. However, it has not been easy to de-segregate GVHD from GVC, since the main effectors for both GVHD and GVC are $\mathrm{T}$ lymphocytes that share many common pathways for these two outcomes.

$\mathrm{T}$ lymphocytes contained in the donor graft have crucial roles in the pathogenesis of GVHD; therefore, prophylaxis of GVHD has been focused on the depletion, tolerization or functional incapacitation of donor T cells [1]. The strategies used for the prophylaxis of GVHD rely on the nature of conditioning regimen, donor type, stem cell source and the degree of HLA mismatch [101,102]. Single pharmacological agents or combination of them have been used in an effort to prevent GVHD after allo-HSCT. Other strategies such as the use of monoclonal antibodies and depletion of T lymphocytes have been used actively in the prophylaxis of GVHD.

Various methods have been tested to manipulate donor $\mathrm{T}$ cells to retain therapeutic effector functions against residual tumor cells in the patient without causing GVHD. In this section, current strategies that are applied in the clinic for the prevention and treatment of GVHD, are reviewed. In addition, emerging strategies and their potential to improve patient outcomes are discussed.

\subsection{Limiting Organ Toxicity by Reducing Intensity of Chemotherapy Conditioning}

A myelosuppressive regimen is administered prior to allo-HSCT to deplete stem cells from the host, thus making more available engraftment space for the donor graft, and to reduce graft rejection mediated by host immune cells [1]. However, the toxicity and the suppressive effects of this regimen usually result in host inflammation and tissue damage that ultimately accelerate the development of GVHD [1]. As an alternative, reduced intensity conditioning regimens using non-myeloablative stem cells transplantation (NM-SCT) therapies have contributed to improve prophylaxis of aGVHD [103,104]. However, reduced-intensity conditioning regimens rely on the beneficial GVC effects of the donor transplant to eliminate residual disease. 


\subsection{Pharmacological Agents Used in Conventional Graft-versus-Host Therapies: Advantages and Drawbacks}

This section summarizes some of the most relevant drugs and therapeutic strategies used for the inhibition or depletion of allo-reactive T cells.

\subsubsection{Inhibition of Allo-Reactive T cells}

Methotrexate (MTX)

MTX inhibits dividing allo-reactive T-cells [105] resulting in protection against GVHD. However, a major limitation of MTX is the observation of aGVHD between HLA-matched siblings [106].

\section{Calcineurin Inhibitors}

Calcineurin inhibitors such as cyclosporine A (CYA) [107], and tacrolimus (FK506) [108] immunosuppress T lymphocytes [109]. These inhibitors prevent GVHD by inhibiting the activation and proliferation of donor $\mathrm{T}$ cells via blocking nuclear factor of activated T cells (NFAT) [107]. CYA also attenuates the expression of IL-2 and IL-2 receptor (IL-2R) in activated T lymphocytes. However, only a mild to moderate prevention of GVHD has been reported in the presence of calcineurin inhibitors.

\section{Corticosteroids}

Corticosteroids at high doses are the first-line treatment for established GVHD [110]; however, a significant role in GVHD prevention has not been established. For instance, trials using prednisone in combination with cyclosporine and/or methotrexate have not demonstrated improved GVHD prophylaxis [107]. On the contrary, studies using cyclosporine and prednisone has been associated with increased risk of cGVHD [111].

Cyclophosphamide

Cyclophosphamide has been used post-transplant since the 1980s for the prevention of aGVHD, which occurs via inhibiting $\mathrm{T}$ cell division and is used after myeloablative conditioning in related and unrelated allo-transplants [112].

Mycophenolate Mofetil (MMF)

MMF has a potent cytostatic effect on T and B lymphocytes [113]. MMF has been used in combination with calcineurin inhibitor and/or methotrexate. However, the incidence of grade II-IV GVHD still ranged between $38 \%$ and 62 [114,115]. Combination of MMF with cyclosporine resulted in faster engraftment, yet the incidence of aGVHD and cGVHD was totally prevented [113].

\section{Sirolimus}

Sirolimus (rapamycin) forms a complex with the mammalian target of rapamycin (mTOR), inhibiting biochemical pathways with the concomitant reduction of DNA transcription/translation of protein synthesis, cell cycle progression, which ultimately result in T cell immunosuppression [113]. Sirolimus, in combination with tacrolimus, has been used with good efficacy against aGVHD. However, no effect was observed against cGVHD. In general, the prevention of GVHD with sirolimus has been mild to moderate.

\subsubsection{Depletion of $T$ lymphocytes}

T cell depletion prophylaxis for GVHD was undertaken in the 1980s, and 1990s. The three main depletion strategies were ex vivo negative selection of T cells, ex vivo positive selection of CD34 ${ }^{+}$ stem/progenitor cells, and use of antibodies against $\mathrm{T}$ cells in vivo. 
In the 1970s, GVHD was lethal in recipients of HLA-mismatched bone marrow [116]. In the 1980s this obstacle was overcome by removing T cells from the allo-graft, resulting in reduced incidence and severity of GVHD [64,109,117]. Differential agglutination with soybean agglutinin (SBA) was initially performed to deplete T cells in murine models [118], and then successfully translated to patients with severe combined immunodeficiency (SCID) using BSA followed by E-rosette depletion with sheep red blood cells $[119,120]$. Even in absence of GVHD prophylaxis, no signs of GVHD were detected $[64,109,117,121]$. Unfortunately, this technique of T cell depletion also led to poor hematopoietic engraftment, increased incidence of disease relapse and increased incidence of opportunistic infections $[109,122,123]$. Using a magnetic bead approach to deplete T cells from G-CSF mobilized peripheral blood stem cells, allo-HSCT recipients developed minimal GVHD and high rate of engraftment [124]. Allograft depletion of CD3/CD19 with anti-CD3/CD19 coated microbeads not only preserved the levels of $\mathrm{CD}_{3} 4^{+}$stem/progenitor cells, but also NK cells and dendritic cells [125]. Depletion of alpha/beta T lymphocyte subsets, which are responsible for the occurrence of GVHD [126], was another graft manipulation strategy that was effective for allo-HSCT [126].Polyclonal Antibodies: In vivo administration of the polyclonal anti-thymocyte globulin (ATG) antibodies, preand peri-allo-HSCT, simultaneously targeted donor and host T cells resulting in the control of GVHD and avoided graft rejection. However, one of the challenges was that the ATG antibodies also target B cells, NK cells and APCs, without reducing the incidence of cGVHD [113].

\section{Monoclonal Antibodies (MAbs)}

MAbs like T10B9, which targets the T-cell receptor, in combination with CYA have been used to minimize graft rejection; however no improvement in long-term survival has been observed. On the contrary disease relapse, and the risk of opportunistic infections were increased [127]. Alemtuzumab (Campath), is a MAb that reduces the risk of GVHD [113]. Alemtuzumab targets the CD52 antigen, which is expressed in the surface of B and T lymphocytes [113]. One advantage of this antibody is that engraftment is feasible and reduces the non-relapsed mortality after related and un-related transplants [128]. Although administration before allo-HSCT, with either related or un-related donors, resulted in a lower incidence of GVHD, alemtuzumab remains in the blood for up to 1-2 months after transplantation resulting in a delay of immune reconstitution with a higher incidence of viral infection and disease relapse [129]. In an attempt to circumvent these obstacles, selective depletion of $\mathrm{T}$ cell subsets including $\mathrm{CD} 4^{+}, \mathrm{CD}^{+}$and $\mathrm{CD} 8^{+}$have been implemented. However, the success of this strategy remains limited $[4,109,130,131]$.

Positive selection of CD34 ${ }^{+}$

$\mathrm{CD} 34^{+}$with immune-magnetic beads is an effective method of depleting allo-reactive donor $\mathrm{T}$ cells prior to transplant, and results in significant reduction of aGVHD and cGVHD [132,133]. However, major limitations of this method are increased risk of infections, which results in $40 \%$ mortality, and a high incidence of cancer recurrence (51\% of patients transplanted) [132,134].

\section{Treatment of Established Graft-versus-Host-Disease}

There is no specific Food and Drug Administration (FDA)-approved treatment for established aGVHD or cGVHD. Currently, the first-line therapy for GVHD is with corticosteroids like prednisone [102]. Corticosteroids suppress the immune response by inhibiting the production of inflammatory cytokines and therefore, reducing inflammation. However, the steroid toxicities and their limited responses are frequent challenges of this therapy. In addition, outcomes for patients with corticosteroid-refractory GVHD (SR-GVHD) are dismal with only 5-30\% long-term survival [135].

Adjuvant topical steroids to reduce the steroid toxicities have been shown to have some success. In a study evaluating oral beclomethasone, this steroid improved outcomes in patients with GI aGVHD [136]. In another study, clobetasol or dexamethasone applied topically reduced the symptoms of oral cGVHD [137]. 
A number of approaches to reduce the symptoms of GVHD that include the use corticosteroids in combination with other agents have been tested. These other agents have included horse rabbit anti-thymocyte globulin ATG; daclizumab, a monoclonal antibody that targets CD25 (IL-2R $\alpha$ ) present on activated T lymphocytes, antibodies against TNF (e.g., etanercept or infliximab), pentostatin, MMF, and sirolimus. Unfortunately, these pharmacological agents administered with corticosteroids failed to improve response rates [135]. and are frequently associated with higher non-relapse mortality [138].

A second line of treatment of GVHD includes the use of anti-metabolites (e.g., mycophenolate mofetil or methotrexare), extracorporeal photopheresis or light therapy, which improve GVHD outcomes in skin, liver, and mouth tissue. Photopheresis is complicated and requires up to six months to see improvement of the GVHD symptoms.

For cGVHD treatment, prolonged administration of corticosteroids in combination with calcineurin inhibitors such as cyclosporine or tacrolimus has been used as a typical standard therapy. However this combination therapy has not improved patient outcomes [113].

Although some of the above mentioned therapies have been used a second-line therapy in the treatment of SR-GVHD, none have been adopted as a standard salvage therapy for either SR-aGVHD or SR-cGVHD. Pre-clinical evidence has indicated that ruxolitinib, an inhibitor of the Janus kinase (JAK) 1 and 2, has potent anti-inflammatory properties [139].

Since activated JAKs are required for T-effector cell responses in different inflammatory diseases, their blockade could reduce GVHD [140]. Using a mouse aGVHD model, Spoerl et al., showed that inhibition of the JAK1/2 signaling with ruxolitinib resulted in reduced proliferation of effector T cells, suppression of production of proinflammatory cytokines in response to mouse allo-antigen, and increase in Foxp $3^{+}$regulatory T cells [140]. Therefore, ruxolitinib may be a promising new therapy for the treatment of SR-GVHD. Recently a retrospective survey involving institutions in United States and Europe, showed high response rates $(>80 \%)$ and 6-month survival rates in patients with SR-aGVHD or SR-cGVHD [139].

Bortezomib, a proteasome inhibitor, was approved by the FDA for treating patients with multiple myeloma and mantle cell lymphoma [141]. Although bortezomib prevents aGVHD in mice, the inhibitor does treat ongoing aGVHD. Recently, bortezomib was evaluated in a sclerodermatous cGVHD mouse model and as a result cutaneous lesions were improved, along with a reduction of germinal center B cells were observed [142]. B cell dysregulation and allo-antigen production are known to play a critical role in the pathogenesis of cGVHD [143]. In addition to this, bortezomib has an inhibitory effect on B cells and plasma cells [144]. Based on the murine results, a pilot human clinical trial with bortezomib for the treatment of cutaneous cGVHD resulted in positive clinical responses with minimal toxicity demonstrating that bortezomib may be a treatment option for patients with SR-cGVHD [142].

\section{Alternative and Novel Strategies to Inhibit Graft-versus-Host Disease}

\subsection{Attenuating Graft-versus-Host Disease by B Cell Depletion}

B cells contribute to immune responses through the production of antibodies, inflammatory cytokines, antigen recognition and other immunoregulatory functions. A growing body of research indicates that in addition to T cells, B cells play an important role in the immune pathology and tissue damage characteristic of GVHD [145]. Thus, the understanding of how B cells contribute to the development of GVHD after allo-HSCT is becoming an active area of investigation [146]. In the setting of allo-HSCT, B-cell-depleting therapy with rituximab has been investigated for the treatment cGVHD [37,145]. Moreover, administration of rituximab prior to allo-HSCT has resulted in reduced incidence and severity of aGVHD $[147,148]$. Rituximab binds to CD20 on B-lymphocytes and malignant lymphoma causing cell destruction via a multifactorial mechanism that includes antibody-dependent cell mediated cytotoxicity, cell lysis, and induction of apoptosis of target cells. Thus, rituximab leads 
to the depletion of B cells. Furthermore, an increase in the suppressive function of Tregs has been observed after the treatment with rituximab [149].

\subsection{Cellular Suicide Gene Therapy}

The cellular suicide gene approach is a promising tool to manipulate donor $\mathrm{T}$ cell effector functions in order to augment the GVC effects, promote immune reconstitution, and to prevent or control GVHD [134]. The cellular suicide gene approach is based on the transfer of a suicide gene into donor lymphocytes, which allow safe infusion of viable active T cells, which can be selectively controlled post-transplant in the event of GVHD. The herpes simplex virus thymidine kinase (HSV-TK) has been widely used as a suicide gene in humans [134]. The HSV-TK is a cell cycle-dependent suicide gene that catalyzes the generation of triphosphate ganciclovir (GCV). GCV inhibits DNA chain elongation, which is toxic for proliferating cells $[150,151]$. In vitro and in vivo preclinical studies and phase I/II clinical trials have demonstrated that the retroviral-mediated transfer of the suicide gene HSV-TK into donor T cells prior to infusion allows for the efficient control of donor T cell allo-reactivity [152]. Importantly, donor suicide gene-modified T cells (SGMTCs) provide beneficial anti-leukemic, anti-viral and immune reconstitution-facilitating effects to recipients of an allo-HSCT [153]. Currently, HSV-TK therapy for GVHD is being evaluated in a phase III clinical trial for high-risk acute leukemia [134].

There are some limitations of the HSV-TK approach. In immunocompromised patients, TK may lead to undesired elimination of transduced cell populations as a result of the immunogenicity of this viral protein. In addition GCV is a drug used to treat cytomegalovirus (CMV) reactivation, which commonly affects immunocompromized patients. Administration of GCV in these patients to treat CMV induces undesired TK-cell killing [134].

A different suicide gene strategy has been explored using inducible human caspase 9 transgene (iC9), which is a hybrid protein consisting of a human FK 506-binding protein (FKBP12) linked to a modified human caspase 9 lacking the caspase recruitment domain (CARD). The iC9 transgene can be dimerized and activated by administration of a bio-inert small molecule drug AP1903. A phase I/II clinical trial suggests that patients had immediate and sustained protection from major pathogens in the absence of aGVHD or cGVHD [154].

\subsection{Regulatory T Cells}

Naturally occurring Tregs are immunophenotypically defined by $\mathrm{CD} 4^{+} \mathrm{CD} 25^{+} \mathrm{Foxp} 3^{+}$. Tregs constitute $5 \%-10 \%$ of peripheral $\mathrm{CD} 4^{+} \mathrm{T}$ cells, and play a pivotal role in the induction of immunologic tolerance and maintenance of immune homeostasis [155,156]. Additionally to inhibit graft rejection of MHC-disparate allografts after sub-lethal conditioning in mice $[123,157,158]$, adoptive transfer of Tregs can prevent GVHD [94,156,159]. However, the low frequency of Tregs $[155,160]$ represents a major obstacle for the clinical application of Tregs for the prevention or treatment of GVHD. This obstacle has been partially overcome by using methods such as in vitro expansion of Tregs through $\mathrm{T}$ cell receptor (TCR)-mediated activation with IL-2 [156], in vitro conversion of conventional T cells (Tcon) into Tregs in the presence of TGF- $\beta$ [161], or via gene transfer of Foxp3, a forkhead-box transcription factor, which is defective in autoimmune and inflammatory syndromes [162]. Nevertheless, the major problem is that none of these methods can produce a homogeneous and stable population of cells with a suppressive capacity equal to that of natural Tregs [163].

In 2010, Cao and co-workers [155] reported the use of a lentivirus-based strategy to express Foxp3 ectopically in mouse $\mathrm{CD} 4^{+} \mathrm{CD} 25^{-} \mathrm{T}$ cells. Using a leukemic model, they demonstrated that the infusion of engineered Tregs in combination with donor bone marrow and splenocytes not only prevented recipients from lethal GVHD, but also the GVC effect was maximally preserved [164]. Although the therapeutic potential of engineered Tregs for the separation of GVHD and the GVC effect have been demonstrated, the determination of the kinetics of the lentiviral transduction and the determination of the potential biosafety issues of lentiviral are still pending before this methods can be applied in clinical trials. 


\subsection{Targeting Co-Stimulatory Molecules}

Co-stimulatory molecules provide the second signal that fully activates alloreactive $\mathrm{T}$ cells. The co-stimulatory pathways are grouped in two major families: the immunoglobulin (Ig) superfamily and the TNF/TNF receptor (TNFR) family. Since co-stimulatory molecules promote GVHD, different therapeutic approaches have been aimed to target and block such molecules. Herein, we briefly describe some of the best-known co-stimulatory molecules and their action of blockade with pharmacological agents to abort GVHD.

\subsubsection{CD137}

CD137 is a member of the TNF receptor family that functions as a co-stimulatory molecule for $\mathrm{T}$ cells. CD137 ligation on $\mathrm{CD} 8^{+} \mathrm{T}$ cells increases $\mathrm{T}$ cell survival proliferation and cytotoxic $\mathrm{T}$ lymphocyte (CTL) activities. The use of anti-CD137L mAb inhibits aGVHD, while exacerbating cGVHD. The anti-CD137L mAb inhibits the activity of donor T cells in the following GVHD mouse models: DBA/2 (donor) $\rightarrow$ F1 (host); and C57BL/6 (donor) $\rightarrow$ F1 (host) [165].

\subsection{2. $\mathrm{CD} 28$}

CD28 is constitutively expressed on naive T cells. CD28 has two ligands, B7-1 and B7-2, which are expressed on APCs; and the activation of T cells induces the up-regulation of these ligands. B7-1 and B7-2 also have high-affinity for the inhibitory receptor named as CTLA-4, whose expression is induced on activated T cells [165]. Reduction in GVHD lethality was observed in mice treated with CTLA-4 Ig or infused with CD28-deficient donor T cells [166-168]. CTLA-4 Ig has been used as a surrogate ligand to block CD28/CTLA-4 T cell co-stimulation. CTLA-4 Ig treatment reduces the initial endogenous cytokine production and arrests the subsequent expansion of donor $\mathrm{T}$ cells, the differentiation of anti-host effectors, and the development of severe immune deficiency [167]. A limitation of this approach is that the blocking effect of CTLA-4 Ig is incomplete, presumably because of redundant roles of CD28 with other co-stimulatory molecules inhibition of Treg cell proliferation and the blockade of the negative signal transduction through CTLA-4, [165]. In another approach, lentiviral vector carrying CD28 shRNA was used to block the CD28/B7 signaling pathway, which allowed inhibition of $\mathrm{T}$ cell proliferation. This method reduced GVHD in a mouse model of allogeneic bone marrow transplantation [169].

\subsubsection{Inducible Co-Stimulator (ICOS)}

ICOS is a member of the CD28 family that is expressed on activated T cells and memory T cells. It is constitutively expressed on B cells, macrophages, and dendritic cells and is upregulated on APCs and some non-lymphoid tissues by TNF or LPS [170]. Blockade or absence of ICOS diminishes GVHD $[170,171]$. Some studies have shown that inhibition of GVHD by ICOS blockade is associated with skewed differentiation towards Th2 cells [171]. However, other studies have showed evidence that blockade of ICOS results in lower proliferation of donor T cells and subsequent inhibition of GVHD [170].

\subsubsection{Programmed Death 1 (PD-1)}

PD-1 is a member of the B7:CD28 superfamily and is involved in keeping the cellular immune system in check. PD-1 is expressed on activated CD4, CD8 T cells, as well as NK cells, B cells, and macrophages. PD-1 has two ligands, PDL-1 and PDL-2 that are expressed on APCs after cellular activation. Some studies have shown that blockade of the PD-1/PD-L1 pathway accelerates GVHD-induced lethality [172]. In accordance with these studies, studies have shown that GVHD is markedly accelerated in donor cells that lack PD-1 [80]. Inhibition of GVHD by PD-1/PD-L1 pathway correlates with the suppression of IFN- $\gamma$ production [80]. Additional studies have shown that the 
PD-1/PD-L1 pathway is important to inhibit GVHD by Tregs. In this regard, the blockade of the PD-1/PD-L1 pathway abrogates the immunoregulation mediated by Tregs [173].

\subsubsection{The CD40/CD40-Ligand (CD40L) Pathway}

CD40L pathway is involved in the GVHD lethality. CD40 is expressed on DCs and B cells, and CD40L is expressed on activated $\mathrm{CD}^{+} \mathrm{T}$ cells. CD40 signals activate DCs and activated DCs promote the activity of $\mathrm{CD}^{+} \mathrm{T}$ cells and $\mathrm{CD} 4^{+} \mathrm{T}$ cells. Studies using a DBA/2 (donor) $\rightarrow \mathrm{F} 1$ (recipient) aGVHD or cGVHD model demonstrated that blockade of the CD40 pathway inhibits aGVHD and cGVHD [174]. Studies using conditioning GVHD models showed that CD40/CD40L interaction increases aGVHD lethality [175] by promoting direct CD4 T cell-mediated tissue damage and CD4 ${ }^{+}$ T-cell proliferation [176]. Apart from the above-mentioned co-stimulatory molecules, inhibition of GVHD has also been possible by blocking members of the TNF superfamily of proteins including OX40, the herpes virus entry mediator (HVEM or TNFRSF14), and CD30. While the OX40/OX40L and CD30/CD30L pathways play a role in the CD4 ${ }^{+}$T cell-mediated GVHD [79], HVEM is involved in $\mathrm{CD}^{+} \mathrm{T}$ cell-mediated GVHD [177].

\subsection{Molecular Targets in T Cells That Modulate Graft-versus-Host Responses}

Recently, intracellular molecular targets in $\mathrm{T}$ cells have been recognized as being critical for regulating alloreactivity. Some of these intracellular targets include epigenetic regulation in donor $\mathrm{T}$ cells, notch signals in donor $\mathrm{T}$ cells, mitochondrial ATPase, the proteasome, protein kinases, microRNAs and the JAK-STAT pathways.

\subsubsection{Epigenetic Regulation in Donor T Cells}

Epigenetic regulation in all cells is modulated via histone acetylation and methylation along with DNA methylation [178]. Histone deacetylase (HDAC) inhibitors are antitumor agents [179]. Some of these drugs have potent anti-inflammatory and immunomodulatory effects. This latter effect has shown therapeutic benefit after allo-HSCT in experimental models of GVHD. The regulation of HDAC by the HDAC inhibitors have been correlated in part with their ability to suppress the host antigen presenting cells such as DCs, Tregs and NK cells [179]. In a murine allogeneic bone marrow transplantation model, the pretreatment of DCs with HDAC inhibitors, such as suberoylanilide hydroxamic acid (SAHA) and ITF2357 reduced TLR-induced secretion of pro-inflammatory cytokines, reducing experimental GVHD [180]. Another study demonstrated that administration of DZnep, an inhibitor of histone methylation, arrested GVHD in mice after allo-HSCT. In this study, DZep promoted selective apoptosis in alloreactive effector T cells [181]. DNA hypo-methylating agents, such as decitabine (Dec) and azacitidine (AzaC), also reduced GVHD in vivo via a direct effects on donor Tregs [182].

\subsubsection{Targeting Notch Signals in Donor T Cells}

Signaling mediated by Notch activation is important in cellular processes such as differentiation, survival and homeostasis [178]. In the setting of allo-HSCT Notch regulates hematopoietic progenitors and allo-immune T cells [183]. In vivo, studies have demonstrated that Notch regulates allo-reactive T cells that mediate GVHD. In mouse allo-HSCT models, inhibition of Notch in donor-derived T cells resulted in the reduction of severity and mortality of GVHD [183,184].

\subsubsection{Targeting Mitochondrial ATPase}

During GVHD T cells proliferate in response to allo-antigens, and this process demands increased levels of ATP as a source of energy. Studies have revealed that proliferation of T cells increased aerobic glycolysis and oxidative phosphorylation. Alloreactive $\mathrm{T}$ cells also display increased superoxide production and decreased amounts of anti-oxidants. Bz423 is an inhibitor of the mitochondrial $F_{1} F_{0}$ adenosine triphosphate synthase $\left(\mathrm{F}_{1} \mathrm{~F}_{0}\right.$-ATPase $)$, which induces selective apoptosis of alloreactive 
$\mathrm{T}$ cells, and reverses GVHD in BMT models without affecting hematopoietic engraftment or the immune reconstitution [185].

\subsubsection{Proteasome Inhibition}

Proteasome inhibition has been shown to induce apoptosis of allo-reactive T cells [178]. Studies performed in mice have demonstrated that proteasome inhibitors such as bortezomib inhibits cytokine signaling and NF- $\mathrm{kB}$ activation [1]. Bortezomib preferentially and selectively depletes allo-reactive T-cells, supports Treg-cell survival, and attenuates IL-6 mediated T cell differentiation [186]. It also attenuates TLR4-mediated APC activation with reduced cytokine production and immunostimulatory activity. Significant protection from GVHD was observed when bortezomib was administrated to mice at the time of allo-BMT [186]. The effect of bortezomib on GVHD depends on the timing of its administration, as delayed administration causes exacerbation of GVHD in the gut, which is correlated with increased levels of type 1 interferon, TNF, interleukin-1beta (IL-1 $\beta$ ) and IL-6 [187]. Thus, more effective methods that selectively deplete T cells from the donor graft may improve patient's outcomes after allo-HSCT.

\subsubsection{Targeting Protein Kinases}

Protein kinase $\mathrm{C} \theta$ (PKC $\theta$ ) maintains the immunological synapse between $\mathrm{T}$ effector (Teff) cells and ligated-APCs, and is a key regulator of T-cell receptor (TCR) signaling. PKC $\theta$ promotes T-cell allo-reactivity and GVHD induction $[188,189]$. Studies using murine models of allo-HSCT have demonstrated that deletion of PKC $\theta$ leads to induction of T cell anergy [189] reducing the severity of GVHD [188]. Protein kinase $\mathrm{C} \alpha(\mathrm{PKC} \alpha)$ has recently been characterized as a cooperative and surrogate $T$ cell activation signaling partner for PKC $\theta$ [190]. In vivo studies have demonstrated that both PKC $\alpha$, and PKC $\theta$ contribute to GVHD. Pharmacological inhibition of PKC $\alpha$ and PKC $\theta$ with R524 prevented GVHD and preserved GVC responses. R524 hampers T cell proliferation in vivo and in vitro, and reduces the expression of chemokine receptors and the production of chemokines, preventing the development of GVHD [191].

\subsubsection{Therapeutic Intervention of GVHD by Targeting microRNAs}

MicroRNAs are small single-stranded noncoding RNAs, which influence molecular pathways that control the development and function of innate and adaptive immune responses [192]. In vivo studies using mouse GVHD models showed that microRNA-155 (miR-155) was up-regulated during activation of T cells after allo-HSCT [193]. Lethal GVHD was markedly reduced in mice receiving miR-155 deficient donor T cells reduced compared with WT control mice [193]. Likewise, blocking miR-155 expression with a synthetic antibody after allo-HSCT decreased the severity of GVHD and prolonged survival in mice [193].

\subsubsection{Targeting Janus Kinase/Signal Transducer and Activator of Transcription Pathways}

Regulation of donor T cells with specific signal transducer and activator of transcription (STAT) family proteins has shed light into the role of these proteins in GVHD regulation. Activation of STAT1 is an early event in GVHD and correlates with early cytokine storm [194]. Experimental evidence has revealed that lack of STAT1 in donor T cells reduced expansion of donor T cells and reduced GVHD [195]. Interestingly, deficiency of STAT1 inhibited the apoptosis of natural Tregs (nTregs), and facilitated the expansion of donor inducible Tregs (iTregs) [195]. STAT3 is another protein in GVHD-signaling pathway. In fact, activation of STAT3 correlates with the release of high levels of pro-inflammatory cytokines like IL-6 and also IL-10 [194]. In addition, studies have shown that elimination of STAT3 correlated with instability of nTregs and inhibition of iTreg cell polarization from naïve $\mathrm{CD}^{+} \mathrm{T}$ cells [196]. Transfer of STAT3-deficient naïve donor $\mathrm{CD} 4^{+} \mathrm{T}$ cells increased nTregs post-BMT and prevent GVHD lethality [196]. Murine model of allo-BMT showed that JAK3 is expressed in T cells and plays a role in the pathogenesis of GVHD [197]. Therefore, targeting JAK3 with the 
inhibitor JANEX-1 has prevented GVHD in mouse models [198]. Overall these studies suggest that targeting the JAK/STAT signaling pathway in donor T cells with small molecules could be effective for controlling GVHD.

\subsection{Virotherapy as a Novel Strategy to Prevent or Control Graft-versus-Host Disease and Augment the Graft-versus-Cancer Effects after Allogeneic Hematopoietic Stem Cell Transplantation}

Oncolytic viruses are promising new agents for targeting and killing cancer cells [199,200]. Among the rich diversity of candidate viruses that have been tested with different cancers, this review will focus on oncolytic MYXV. A prototypic member of the Leporipoxvirus genus of the Poxviridae family, MYXV causes the lethal disease called myxomatosis in European rabbits (Oryctolagus cuniculus) [201,202]. Interestingly, the virus is non-pathogenic for any host outside the lagomorph family, failing to propagate in any non-rabbit species, including immunodeficient mice and humans $[201,203,204]$. Despite its narrow host range in nature, MYXV productively infects and replicates in a wide diversity of human cancer cells. Two main factors have been characterized to date that render cancer cells more susceptible to MYXV infection. First, most cancer cells fail to mount a fully competent innate anti-viral response such as the synergistic effects of type I interferon and tumor necrosis factor pathways, which efficiently abort MYXV replication in normal primary human cells $[205,206]$. Second, many cancer cells have elevated levels of activated kinases such as Akt, which upregulate MYXV replication in cancer cells [207]. Thus, the induced activation of Akt using pharmacological manipulation can enhance MYXV replication in some refractory cancer cells, which are otherwise non-permissive [208]. The ability of MYXV to manipulate other intracellular anti-viral signaling pathways can also determine whether the virus will replicate in cancer cells, for example, via the inhibition of PKR signaling pathway. The MYXV dsRNA-binding protein M029 is essential for inhibition of PKR activation and replication in human cancer cells [209]. In another study it was also observed that MYXV preferentially infects cancer cells that possess dysfunctional or deleted p53, ATM and Rb tumor suppressor genes $[207,210,211]$. Studies evaluating MYXV have demonstrated the ability of this virus to target and kill many diverse human or murine cancers, including myeloid leukemia, multiple myeloma (MM) [5,8,212-214], melanoma, glioblastoma, ovarian cancer, and pancreatic cancer [214]. Importantly, these studies have demonstrated that MYXV selectively targets and kills malignant human hematopoietic cells such as leukemia cells, (MM), while sparing normal hematopoietic stem and progenitor cells (HSPCs) $[8,213]$. Therefore, MYXV is being developed as a novel ex vivo purging agent to functionally eliminate specific malignant cell populations from human hematopoietic stem cell transplants $[8,9,212,213]$.

\subsubsection{Ex Vivo Treatment with MYXV Prevents GVHD in a Xeno-Transplanted NSG Murine Model}

Recently, we reported that immunodeficient NSG mice xeno-transplanted with MYXV-pretreated human HSPC samples, such as BM or PBMCs, showed prolonged survival times compared to mock-treated transplant controls (e.g., without ex vivo MYXV treatment) [12]. In this model, sub-lethally irradiated adult NSG mice injected with either normal human BM or PBMCs displayed a lethal wasting disease by four to six weeks after transplant. The clinical presentation of this xeno-transplant-induced disease involved significant edema, and infiltration of $\mathrm{CD}^{+} \mathrm{T}$ cells into the liver, intestines, skin, lung, kidney and spleen, consistent with the classic pathology of allo-HSCT GVHD. On the other hand, mice injected with human BM or PBMCs that had been pretreated ex vivo with MYXV for $1 \mathrm{~h}$ prior to transplant survived until the time of sacrifice without evidence for the disease [12]. This study also demonstrated that the GVHD disease observed in the mock-treated xeno-transplanted recipients required mature human donor $\mathrm{CD}^{+} \mathrm{T}$ lymphocytes. In addition, ex vivo MYXV treatment of human HCT samples did not impair normal human hematopoietic stem and progenitor cell (HSPC) engraftment in the immunocompromised NSG recipients and yet selectively inhibited expansion of transferred donor $\mathrm{CD}^{+} \mathrm{T}$ cells in the transplant recipient tissues such as spleen, liver and lungs [12]. These results suggest that ex vivo pre-treatment of the human HCT specimens with MYXV attenuated 
the subsequent induction of GVHD. Importantly, the ex vivo MYXV treatment did not compromise the ability of the donor human HCT to mediate GVC as assessed by the elimination of pre-seeded human U266 MM in the majority of the recipient NSG mice.

In the same study, human-to-human haplo-mismatched mixed lymphocyte reactions (MLRs) were also tested to investigate whether MYXV could prevent the expansion of allo-reactive lymphocytes in the context of human antigen allo-stimulation. The results indicated that MYXV prevented responder cell proliferation in the MLRs, suggesting that MYXV prevents the expansion of alloreactive lymphocytes from primary human BM samples when stimulated with HLA-mismatched human donor leukocyte samples [12].

To summarize, two striking results were derived from this work [13]. First, ex vivo MYXV treatment for just $1 \mathrm{~h}$ prior to transplant affects the post-transplant activities of primary human $\mathrm{CD}^{+} \mathrm{T}$ lymphocytes found in HCT samples derived from either BM or PBMCs. Second, this ex vivo treatment of human HCT samples with MYXV delayed or eliminated the development of lethal GVHD in xeno-transplanted NSG mice, while sparing the GVC effects.

\subsubsection{MYXV Effects on Human T Cells}

Although ex vivo virotherapy with MYXV prevented GVHD caused by human T cells in the allo-HSCT xeno-transplant model [12], the mechanism by which the virus treatment prevented GVHD remained unexplained. However, recent in vitro studies performed with MYXV revealed that MYXV prevented GVHD by impairing the subsequent functionality of human T lymphocytes from the donor transplant [13]. This study demonstrated that, although MYXV binds to resting human CD3 ${ }^{+} \mathrm{T}_{\text {cells, }}$ the activation of these virus-bound $\mathrm{T}$ cells is required to launch productive infection with MYXV. Importantly, the activation of MYXV-adsorbed human T cells caused the inhibition or suppression of T cell proliferation, as well as the downregulation of effector molecules such as IL-2, IL-2R $\alpha$ and IFN- $\gamma$. These results help explain the mechanism by which ex vivo MYXV virotherapy prevents GVHD in the xenogeneic model [12]. Furthermore, these studies also demonstrated that MYXV can exploit activated human $\mathrm{T}$ cells as a cell carriers that can donate virus to infect and kill human MM cells (Figure 2 illustrates the proposed mechanism). Together, these in vitro studies suggest a dual role of ex vivo MYXV virotherapy to prevent GVHD, but yet also augment the GVC effects of donor human lymphocytes [13]. 


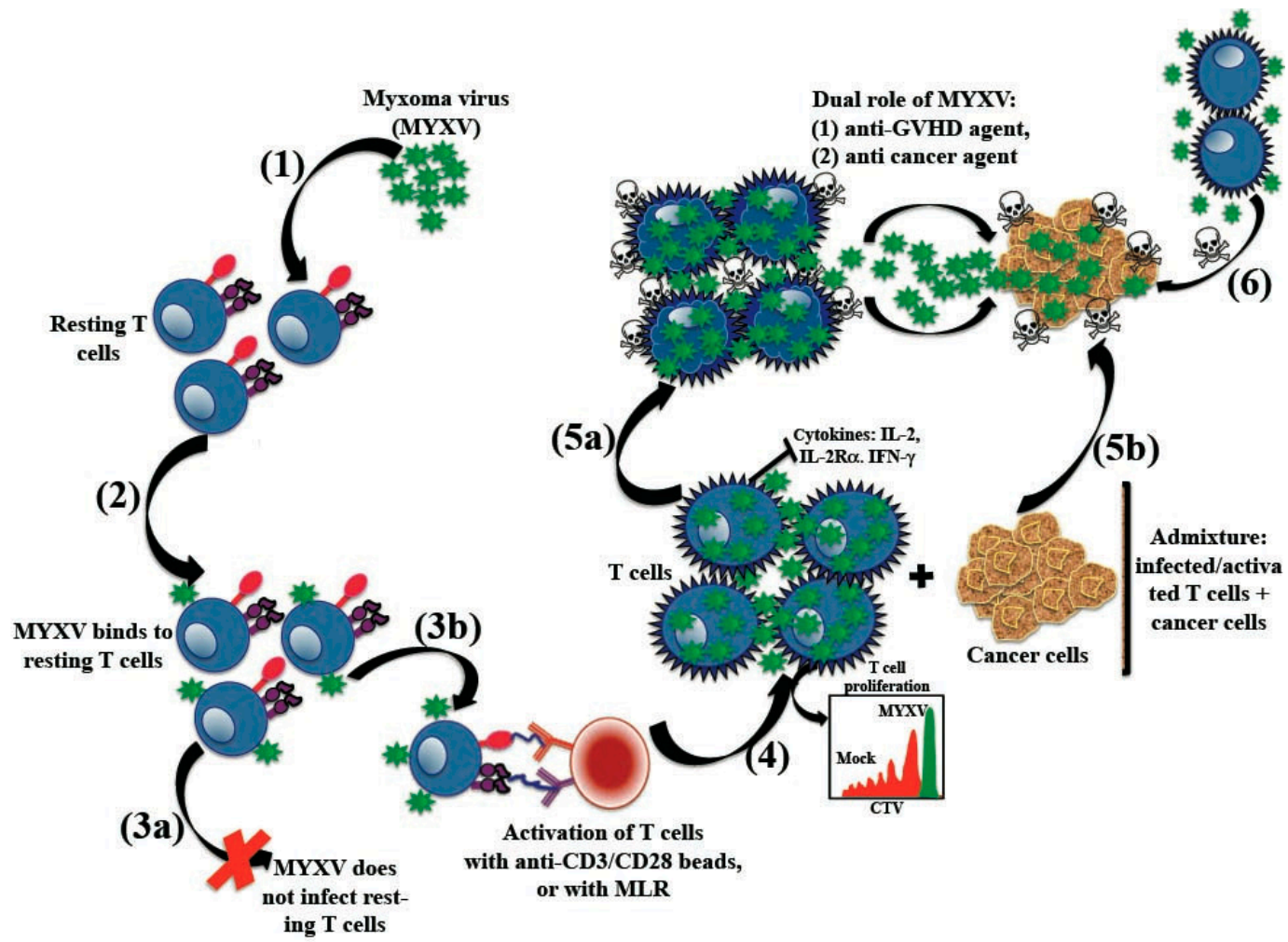

Figure 2. Dual effects of ex vivo virotherapy with myxoma virus: preventing graft-versus-host disease and yet preserving or augmenting graft-versus-cancer. Myxoma virus (MYXV) prevents graft-versus-host disease (GVHD) and improves the graft-versus-cancer (GVC) effects in six steps. (1) MYXV targets and (2) binds to resting human T cells in transplant samples. However, (3a) MYXV infection does not progress past the binding step in resting $\mathrm{T}$ cells unless ( $3 \mathrm{~b}$ ) $\mathrm{T}$ cells are stimulated (e.g., via anti-CD3/CD28 beads) or by allostimulation (e.g., via mixed lymphocyte reactions) when contacting allo-antigen in recipient tissues. (4) MYXV impairs T cell proliferation and secretion or endogenous production of inflammatory cytokines that fuel GVHD, including IL-2, IL-2R- $\alpha$ (CD25) and IFN- $\gamma$. (5a) MYXV reduces the viability of T cell inducing accelerated cell death. (5b) MYXV uses activated T cells as cell carriers to ferry virus to reach residual cancer cells in the transplant recipient. Once delivered, viral particles migrate from $\mathrm{T}$ cells to contacted cancer cells. This is followed by infection and killing of the target cancer cells. (6) In addition to this, activated T cells exposed to MYXV, but not productively infected, also become more efficient killers of cancer cells, suggesting that MYXV arms T cells to upregulate cytotoxic killing pathways against cancer cells, in addition to delivering oncolytic virus to the residual cancer.

\subsubsection{MYXV Has a Dual Role as Anti-GVHD and Anti-Cancer Agent}

Adoptive transfer of mature T cells contained in the allo-HSCT improves patient prognosis through the highly beneficial anti-tumor effects of GVC, which relies on donor T cells becoming engaged and activated in clearance of minimal residual disease [130]. This GVC effect, however, is eliminated upon complete depletion of donor T lymphocytes, a common strategy (whether chemically or physically) used to prevent GVHD. Since ex vivo MYXV virotherapy of human BM or PBMCs prevented GVHD in a xeno-transplanted model and yet poorly infected resting human T cells ex vivo, one intriguing question that needed to be addressed was how MYXV selectively prevented GVHD while still permitting GVC against pre-seeded human myeloma. Thus, by exploiting a xeno-transplant model that assessed both GVC and GVHD, we demonstrated that MYXV prevented GVHD did not impair either the GVC effects of the human HSPC transplant graft or the engraftment of the normal stem cells [12]. Importantly, the ex vivo pre-treatment of human BM with MYXV, followed 
by infusion in immuno-compromised mice with pre-seeded human myeloma, was a more effective anti-cancer strategy than just the direct injection of free MYXV virions, supporting the conclusion that the intravenous injection of free virus did not reach the pre-seeded disease in the BM as efficiently as when delivered via transplant leukocytes loaded ex vivo with virus [12]. Very recently, it was demonstrated that MYXV can exploit activated human T cells as cell carriers to deliver virus to human myeloma cells [13] (Figure 2). Interestingly, both input virus ("passive" mechanism) and progeny virus ("active" mechanism) from the infected T cells can be transferred to the target cancer cells. This infection leads to rapid cancer cell death, consisting with the oncolytic effects of MYXV infection on many human cancer cells (Figure 2). Interestingly, stimulated $\mathrm{T}$ cells that were not productively infected with MYXV in addition became better killers of cancer cells, suggesting that $\mathrm{T}$ cells exposed to MYXV are also better armed to kill cancer cells by direct cytolysis. These latter results indicate that MYXV enhances the beneficial effects of GVC by multiple mechanisms [13]. Thus far, MYXV is the only live oncolytic virus that has been exploited for the prevention of GVHD.

\section{Conclusions}

Despite significant progress in allo-HSCT, GVHD remains a major clinical complication of this therapy. Many therapeutic strategies have emerged in the last two decades with the aims of preventing or controlling GVHD and improving patient outcomes after allo-HSCT. Unfortunately, most strategies also reduce GVC against residual disease remaining in the patient and have only shown incremental benefits in mitigating GVHD. Development of safer strategies to prevent and treat GVHD, while still preserving or even augmenting GVC, will particularly help higher-risk transplant populations. Populations at higher risk for GVHD include those who are older or lack a suitably matched donor, including racial and ethnic minorities. Ex vivo oncolytic virotherapy with MYXV may be a promising strategy for preventing GVHD while simultaneously augmenting GVC. In this regard, understanding the molecular mechanism(s) by which MYXV mediates these dual effects will be critical to translate this new technology to the clinic.

Acknowledgments: The Leukemia \& Lymphoma Society awarded a Scholar in Clinical Research grant to CRC (2500-13). NYV was supported by an endowment by the Pierre Chagnon Professorship at the University of Florida.

Conflicts of Interest: GM is a consultant for DNAtrix and SillaJen, who are conducting human clinical trials with oncolytic viruses. GM and CRC are inventors in a patent held by the University of Florida for the use of MYXV in the prevention and control of GVHD.

\section{References}

1. Blazar, B.R.; Murphy, W.J.; Abedi, M. Advances in graft-versus-host disease biology and therapy. Nat. Rev. Immunol. 2012, 12, 443-458. [CrossRef] [PubMed]

2. Jamil, M.O.; Mineishi, S. State-of-the-art acute and chronic GVHD treatment. Int. J. Hematol. 2015, 101, 452-466. [CrossRef] [PubMed]

3. Weiden, P.; Flournoy, N.; Thomas, E.D.; Prentice, R.; Feter, A.; Buckner, C.D.; Storb, R. Antileukemic effect of graft-versus-host disease in human recipients of allogeneic-marrow grafts. N. Engl. J. Med. 1979, 300, 1068-1073. [CrossRef] [PubMed]

4. Ferrara, J.L.; Levine, J.E.; Reddy, P.; Holler, E. Graft-versus-host disease. Lancet 2009, 273, 1550-1561. [CrossRef]

5. Bais, S.; Bartee, E.; Rahman, M.M.; McFadden, G.; Cogle, C.R. Oncolytic virotherapy for hematological malignancies. Adv. Virol. 2012, 2012, 1-8. [CrossRef] [PubMed]

6. Chan, W.M.; Bartee, E.C.; Moreb, J.S.; Dower, K.; Connor, J.H.; McFadden, G. Myxoma and vaccinia viruses bind differentially to human leukocytes. J. Virol. 2013, 87, 4445-44460. [CrossRef] [PubMed]

7. Villa, N.Y.; Bartee, E.; Mohamed, M.R.; Rahman, M.M.; Barrett, J.W.; McFadden, G. Myxoma and vaccinia viruses exploit different mechanisms to enter and infect human cancer cells. Virology 2010, 401, 266-279. [CrossRef] [PubMed]

8. Bartee, E.; Chan, W.M.; Moreb, J.S.; Cogle, C.R.; McFadden, G. Selective purging of human multiple myeloma cells from autologous stem cell transplantation grafts using oncolytic myxoma virus. Biol. Blood Marrow Transplant. 2012, 18, 1540-1551. [CrossRef] [PubMed] 
9. Madlambayan, G.J.; Bartee, E.; Kim, M.; Rahman, M.M.; Meacham, A.; Scott, E.W.; McFadden, G.; Cogle, C.R. Acute myeloid leukemia targeting by myxoma virus in vivo depends on cell binding but not permissiveness to infection in vitro. Leuk Res. 2012, 36, 619-624. [CrossRef] [PubMed]

10. Chan, W.M.; McFadden, G. Oncolytic Poxviruses. Annu. Rev. Virol. 2014, 1, 119-141. [CrossRef] [PubMed]

11. Kim, M.; Rahman, M.M.; Cogle, C.R.; McFadden, G. Prevention of EBV lymphoma development by oncolytic myxoma virus in a murine xenograft model of post-transplant lymphoproliferative disease. Biochem. Buophys Res. Commun. 2015, 462, 283-287. [CrossRef] [PubMed]

12. Bartee, E.; Meacham, A.; Wise, E.; Cogle, C.R.; McFadden, G. Virotherapy using myxoma virus prevents lethal graft-versus-host disease following xeno-transplantation with primary human hematopoietic stem cells. PLOS ONE 2012, 7, e43298. [CrossRef] [PubMed]

13. Villa, N.Y.; Wasserfall, C.H.; Meacham, A.M.; Wise, E.; Chan, W.; Wingard, J.R.; McFadden, G.; Cogle, C.R. Myxoma virus suppresses proliferation of activated $\mathrm{T}$ lymphocytes yet permits oncolytic virus transfer to cancer cells. Blood 2015, 125, 3778-3788. [CrossRef] [PubMed]

14. Baron, F.; Storb, R. Allogeneic hematopoietic cell transplantation as treatment for hematological malignancies: A review. Springer Semin. Immunopathol. 2004, 26, 71-94. [CrossRef] [PubMed]

15. Jacobson, L.O.; Simons, E.L.; Marrks, E.K.; Robson, M.J.; Bethard, W.F.; Gaston, E.O. The role of the spleen in radiation injury and recovery. J. Lab. Clin. Med. 1950, 35, 746-770. [PubMed]

16. Lorenz, E.; Uphoff, D.; Reid, T.R.; Shelton, E. Modification of irradiation injury in mice and guinea pigs by bone marrow injections. J. Natl. 1951, 12, 197-201.

17. Gatti, R.A.; Meuwissen, H.J.; Allen, H.D.; Hong, R.; Good, R.A. Immunological reconstitution of sexlinked lymphopenic immunological deficiency. Lancet 1968, 2, 1366-1369. [CrossRef]

18. Rocha, V.; Locatelli, F. Searching for alternative hematopoietic stem cell donors for pediatric patients. Bone Marrow Transplant. 2008, 41, 207-214. [CrossRef] [PubMed]

19. Schmitz, N.; Dreger, P.; Suttorp, M.; Rohwedder, E.B.; Haferlach, T.; Löffler, H.; Hunter, A.; Russell, N.H. Primary transplantation of allogeneic peripheral blood progenitor cells mobilized by filgrastim (granulocyte colony-stimulating factor). Blood 1995, 85, 1666-1672. [PubMed]

20. Welniak, L.A.; Blazar, B.R.; Murphy, W.J. Immunobiology of allogeneic hematopoietic stem cell transplantation. Annu. Rev. Immunol. 2007, 25, 139-170. [CrossRef] [PubMed]

21. Barker, J.N.; Weisdorf, D.J.; DeFor, T.E.; Blazar, B.R.; McGlave, P.B.; Miller, J.S.; Verfaillie, C.M.; Wagner, J.E. Transplantation of 2 partially HLA-matched umbilical cord blood units to enhance engraftment in adults with hematologic malignancy. Blood 2005, 105, 1343-1347. [CrossRef] [PubMed]

22. Rocha, V.; Labopin, M.; Sanz, G.; Arcese, W.; Schwerdtfeger, R.; Bosi, A.; Jacobsen, N.; Ruutu, T.; de Lima, M.; Finke, J.; et al. Transplants of umbilical-cord blood or bone marrow from unrelated donors in adults with acute leukemia. N. Engl. J. Med. 2004, 351, 2276-2285. [CrossRef] [PubMed]

23. Laughlin, M.J.; Eapen, M.; Rubinstein, P.; Wagner, J.E.; Zhang, M.J.; Champlin, R.E.; Stevens, C.; Barker, J.N.; Gale, R.P.; Lazarus, H.M.; et al. Outcomes after transplantation of cord blood or bone marrow from unrelated donors in adults with leukemia. N. Engl. J. Med. 2004, 351, 2265-2275. [CrossRef] [PubMed]

24. Holtick, U.; Chemnitz, J.M.; Hallek, M.; Scheid, C. Allogeneic haematopoietic stem cell transplantation-An overview. Klin. Monbl. Augenheiikd. 2015, 232, 641-646.

25. Markey, K.A.; MacDonald, K.P.; Hill, G.R. The biology of graft-versus-host disease: Experimental systems instructing clinical practice. Blood 2014, 124, 354-362. [CrossRef] [PubMed]

26. Choi, S.W.; Reddy, P. Current and emerging strategies for the prevention of graft-versus-host disease. Nat. Rev. Clin. Oncol. 2014, 11, 536-547. [CrossRef] [PubMed]

27. Pasquini, M.C.; Wang, Z.; Horowitz, M.M.; Gale, R.P. 2010 report from the Center for International Blood and Marrow Transplant Research (CIBMTR): Current uses and outcomes of hematopoietic cell transplants for blood and bone marrow disorders. Clin. Transpl. 2010, 87-105.

28. Barnes, D.W.; Loutit, J.F.; Micklem, H.S. "Secondary disease" of radiation chimeras: A syndrome due to lymphoid aplasia. Ann. N. Y. Acad. Sci. 1962, 99, 374-385. [CrossRef] [PubMed]

29. Billingham, R.E. The biology of graft-versus-host reactions. Harvey Lect. 1977-1967, 62, 21-78.

30. Korngold, R.; Sprent, J. Lethal graft-versus-host disease after bone marrow transplantation across minor histocompatibility barriers in mice. Prevention by removing mature T-cells from marrow. J. Exp. Med. 1978, 148, 1687-1698. [CrossRef] [PubMed] 
31. Shlomchik, W.D.; Couzens, M.S.; Tang, C.B.; McNiff, J.; Robert, M.E.; Liu, J.; Shlomchik, M.J.; Emerson, S.G. Prevention of graft versus host disease by inactivation of host antigen-presenting cells. Science 1999, 285, 412-415. [CrossRef] [PubMed]

32. Reddy, P.; Maeda, Y.; Liu, C.; Krijanovski, O.I.; Korngold, R.; Ferrara, J.L. A crucial role for antigen-presenting cells and alloantigen expression in graft-versus-leukemia responses. Nat. Med. 2005, 11, 1244-1249. [CrossRef] [PubMed]

33. Matte, C.C.; Liu, J.; Cormier, J.; Anderson, B.E.; Athanasiadis, I.; Jain, D.; McNiff, J.; Shlomchik, W.D. Donor APCs are required for maximal GVHD but not for GVL. Nat. Med. 2004, 10, 987-992. [CrossRef] [PubMed]

34. Paczesny, S.; Hanauer, D.; Sun, Y.; Reddy, P. New perspectives on the biology of acute GCHD. Bone Marrow Transplant. 2010, 45, 1-11. [CrossRef] [PubMed]

35. Shimabukuro-Vornhagen, A.; Hallek, M.J.; Storb, R.F.; von Bergwelt-Baildon, M.S. The role of B cells in the pathogenesis of graft-versus-host disease. Blood 2009, 114, 4919-4927. [CrossRef] [PubMed]

36. Sarantopoulos, S.; Ritz, J. Aberrant B-cell homeostasis in chronic GVHD. Blood 2015, 125, $1703-1707$. [CrossRef] [PubMed]

37. Kim, S.J.; Won, J.H. B cell homeostasis and the development of chronic graft-versus-host disease: Implications for B cell-depleting therapy. Leuk. Lymphoma 2012, 53, 19-25. [CrossRef] [PubMed]

38. Wysocki, C.A.; Panoskaltsis-Mortari, A.; Blazar, B.R.; Serody, J.S. Leukocyte migration and graft-versus-host disease. Blood 2005, 105, 4191-4199. [CrossRef] [PubMed]

39. Zeiser, R.; Penack, O.; Holler, E.; Idzko, M. Danger signals activating innate immunity in graft-versus-host disease. J. Mol. Med. (Berl.) 2011, 89, 833-845. [CrossRef] [PubMed]

40. Hill, G.R.; Crawford, J.M.; Cooke, K.R.; Brinson, Y.S.; Pan, L.; Ferrara, J.L. Total body irradiation and acute graft-versus-host disease: The role of gastrointestinal damage and inflammatory cytokines. Blood 1997, 90 , 3204-3213. [PubMed]

41. Hill, G.R.; Ferrara, J.L.; Tabilio, A. The primacy of the gastrointestinal tract as a target organ of acute graft-versus-host disease: Rationale for the use of cytokine shields in allogeneic bone marrow transplantation. Blood 2000, 95, 2754-2759. [PubMed]

42. Socié, G.; Blazar, B.R. Acute graft-versus-host disease: From the bench to the bedside. Blood 2009, 114, 4327-4336. [CrossRef] [PubMed]

43. Braun, M.Y.; Lowin, B.; French, L.; Acha-Orbea, H.; Tschopp, J. Cytotoxic T cells deficient in both functional fas ligand and perforin show residual cytolytic activity yet lose their capacity to induce lethal acute graft-versus-host disease. J. Exp. Med. 1996, 183, 657-661. [CrossRef] [PubMed]

44. Csencsits, K.L.; Bishop, D.K. Contrasting alloreactive CD4+ and CD8+ T cells: There's more to it than MHC restriction. Am. J. Transplant. 2003, 3, 107-115. [CrossRef] [PubMed]

45. Kagi, D.; Vignaux, F.; Ledermann, B.; Bürki, K.; Depraetere, V.; Nagata, S.; Hengartner, H.; Golstein, P. Fas and perforin pathways as major mechanisms of T cellmediated cytotoxicity. Science 1994, 265, 528-530. [CrossRef] [PubMed]

46. Van den Brink, M.R.; Burakoff, S.J. Cytolytic pathways in haematopoietic stem-cell transplantation. Nat. Rev. Immunol. 2002, 2, 273-281. [CrossRef] [PubMed]

47. Pan, G.; O’Rourke, K.; Chinnaiyan, A.M.; Gentz, R.; Ebner, R.; Ni, J.; Dixit, V.M. The receptor for the cytotoxic ligand TRAIL. Science 1997, 276, 111-113. [CrossRef] [PubMed]

48. Chicheportiche, Y.; Bourdon, P.R.; Xu, H.; Hsu, Y.M.; Scott, H.; Hession, C.; Garcia, I.; Browning, J.L. TWEAK, a new secreted ligand in the tumor necrosis factor family that weakly induces apoptosis. J. Biol. Chem. 1997, 272, 32401-32410. [CrossRef] [PubMed]

49. Schwab, L.; Goroncy, L.; Palaniyandi, S.; Gautam, S.; Triantafyllopoulou, A.; Mocsai, A.; Reichardt, W.; Karlsson, F.J.; Radhakrishnan, S.V.; Hanke, K.; et al. Neutrophil granulocytes recruited upon translocation of intestinal bacteria enhance graft-versus-host disease via tissue damage. Nat. Med. 2014, 20, 648-654. [CrossRef] [PubMed]

50. Giroux, M.; Delisle, J.S.; Gauthier, S.D.; Heinonen, K.M.; Hinsinger, J.; Houde, B.; Gaboury, L.; Brochu, S.; Wu, J.; Hébert, M.J.; et al. SMAD3 prevents graft-versus-host disease by restraining Th1 differentiation and granulocyte-mediated tissue damage. Blood 2011, 117, 1734-1744. [CrossRef] [PubMed]

51. Socié, G.; Mary, J.Y.; Lemann, M.; Daneshpouy, M.; Guardiola, P.; Meignin, V.; Ades, L.; Esperou, H.; Ribaud, P.; Devergie, A.; et al. Prognostic value of apoptotic cells and infiltrating neutrophils in graft-versus-host disease of the gastrointestinal tract in humans: TNF and Fas expression. Blood 2004, 103, 50-57. [CrossRef] [PubMed] 
52. Tester, A.M.; Cox, J.H.; Connor, A.R.; Starr, A.E.; Dean, R.A.; Puente, X.S.; López-Otín, C.; Overall, C.M. LPS responsiveness and neutrophil chemotaxis in vivo require PMN MMP-8 activity. PLoS ONE 2007, 2, e312. [CrossRef] [PubMed]

53. Sena, L.A.; Li, S.; Jairaman, A.; Prakriya, M.; Ezponda, T.; Hildeman, D.A.; Wang, C.R.; Schumacker, P.T.; Licht, J.D.; Perlman, H.; et al. Mitochondria are required for antigen-specific T cell activation through reactive oxygen species signaling. Immunity 2013, 38, 225-236. [CrossRef] [PubMed]

54. Li, M.O.; Wan, Y.Y.; Sanjabi, S.; Robertson, A.K.; Flavell, R.A. Transforming growth factor-beta regulation of immune responses. Annu. Rev. Immunol. 2006, 24, 99-146. [CrossRef] [PubMed]

55. Garnett, C.; Apperley, J.F.; Pavli̊, J. Treatment and management of graft-versus-host disease: Improving response and survival. Ther. Adv. Hematol. 2013, 4, 366-378. [CrossRef] [PubMed]

56. Broady, R.; Yu, J.; Chow, V.; Tantiworawit, A.; Kang, C.; Berg, K.; Martinka, M.; Ghoreishi, M.; Dutz, J.; Levings, M.K. Cutaneous GVHD is associated with the expansion of tissue-localized Th1 and not Th17 cells. Blood 2010, 116, 5748-5751. [CrossRef] [PubMed]

57. Imanguli, M.M.; Swaim, W.D.; League, S.C.; Gress, R.E.; Pavletic, S.Z.; Hakim, F.T. Increased T-bet+ cytotoxic effectors and type I interferon-mediated processes in chronic graft-versus-host disease of the oral mucosa. Blood 2009, 113, 3620-3630. [CrossRef] [PubMed]

58. Murphy, W.J.; Welniak, L.A.; Taub, D.D.; Wiltrout, R.H.; Taylor, P.A.; Vallera, D.A.; Kopf, M.; Young, H.; Longo, D.L.; Blazar, B.R. Differential effects of the absence of interferon-gamma and IL-4 in acute graft-versus-host disease after allogeneic bone marrow transplantation in mice. J. Clin. Investig. 1998, 102, 1742-1748. [CrossRef] [PubMed]

59. Nikolic, B.; Lee, S.; Bronson, R.T.; Grusby, M.J.; Sykes, M. Th1 and Th2 mediate acute graft-versus-host disease, each with distinct end-organ targets. J. Clin. Investig. 2000, 105, 1289-1298. [CrossRef] [PubMed]

60. Ratajczak, P.; Janin, A.; Peffault de Latour, R.; Leboeuf, C.; Desveaux, A.; Keyvanfar, K.; Robin, M.; Clave, E.; Douay, C.; Quinquenel, A.; et al. Th17/Treg ratio in human graft-versus-host disease. Blood 2010, 116, 1165-1171. [CrossRef] [PubMed]

61. Flowers, M.E.; Inamoto, Y.; Carpenter, P.A.; Lee, S.J.; Kiem, H.P.; Petersdorf, E.W.; Pereira, S.E.; Nash, R.A.; Mielcarek, M.; Fero, M.L.; et al. Comparative analysis of risk factors for acute graft-versus-host disease and for chronic graft-versus-host disease according to National Institutes of Health consensus criteria. Blood 2011, 117, 3214-3219. [CrossRef] [PubMed]

62. Ferrara, J.L.; Reddy, P. Pathophysiology of graft-versus-host disease. Semin. Hematol. 2006, 43, 3-10. [CrossRef] [PubMed]

63. Ferrara, J.L. Novel strategies for the treatment and diagnosis of graft-versus-host-disease. Best Preact. Res. Clin. Haematol. 2007, 20, 91-97. [CrossRef] [PubMed]

64. Vargas-Díez, E.; García-Díez, A.; Marín, A.; Fernández-Herrera, J. Life-threatening graft-vs-host disease. Clin. Dermatol. 2005, 23, 285-300. [CrossRef] [PubMed]

65. Flomenberg, N.; Baxter-Lowe, L.A.; Confer, D.; Fernandez-Vina, M.; Filipovich, A.; Horowitz, M.; Hurley, C.; Kollman, C.; Anasetti, C.; Noreen, H.; et al. Impact of HLA class I and class II high-resolution matching on outcomes of unrelated donor bone marrow transplantation: HLA-C mismatching is associated with a strong adverse effect on transplantation outcome. Blood 2004, 104, 1923-1930. [CrossRef] [PubMed]

66. Carreras, E.; Jiménez, M.; Gómez-García, V.; de la Cámara, R.; Martín, C.; Martínez, F.; Iriondo, A.; Sanz, G.; Cañizo, C.; Cabrera, R.; et al. Donor age and degree of HLA matching have a major impact on the outcome of unrelated donor haematopoietic cell transplantation for chronic myeloid leukaemia. Bone Marrow Transplant. 2006, 37, 33-40. [CrossRef] [PubMed]

67. Deeg, H.J.; Antin, J.H. The clinical spectrum of acute graft-versus-host disease. Semin. Hematol. 2006, 43, 24-31. [CrossRef] [PubMed]

68. Choi, E.Y.; Christianson, G.J.; Yoshimura, Y.; Sproule, T.J.; Jung, N.; Joyce, S.; Roopenian, D.C. Immunodominance of $\mathrm{H} 60$ is caused by an abnormally high precursor $\mathrm{T}$ cell pool directed against its unique minor histocompatibility antigen peptide. Immunity 2002, 17, 593-603. [CrossRef]

69. Bolaños-Meade, J.; Vogelsang, G.B. Acute graft-versus-host disease. Clin. Adv. Hematol. Oncol. 2004, 2, 672-682. [PubMed]

70. Medzhitov, R. Recognition of microorganisms and activation of the immune response. Natute 2007, 449, 819-826. [CrossRef] [PubMed] 
71. Ferrara, J.L.; Levy, R.; Chao, N.J. Pathophysiologic mechanisms of acute graft-vs.-host disease. Biol. Blood Marrow Transplant. 1999, 5, 347-356. [CrossRef]

72. Chen, X.; Das, R.; Komorowski, R.; Beres, A.; Hessner, M.J.; Mihara, M.; Drobyski, W.R. Blockade of interleukin-6 signaling augments regulatory T-cell reconstitution and attenuates the severity of graft-versus-host disease. Blood 2009, 114, 891-900. [CrossRef] [PubMed]

73. Wilhelm, K.; Ganesan, J.; Müller, T.; Dürr, C.; Grimm, M.; Beilhack, A.; Krempl, C.D.; Sorichter, S.; Gerlach, U.V.; Jüttner, E.; et al. Graft-versus-host disease is enhanced by extracellular ATP activating P2X7R. Nat. Med. 2010, 16, 1434-1438. [CrossRef] [PubMed]

74. Franchi, L.; Núñez, G. Orchestrating inflammasomes. Science 2012, 337, 1299-1300. [CrossRef] [PubMed]

75. Jankovic, D.; Ganesan, J.; Bscheider, M.; Stickel, N.; Weber, F.C.; Guarda, G.; Follo, M.; Pfeifer, D.; Tardivel, A.; Ludigs, K.; et al. The Nlrp3 inflammasome regulates acute graft-versus-host disease. J. Exp. Med. 2013, 210, 1899-1910. [CrossRef] [PubMed]

76. Li, X.C.; Rothstein, D.M.; Sayegh, M.H. Costimulatory pathways in transplantation: Challenges and new developments. Immunol. Rev. 2009, 229, 271-293. [CrossRef] [PubMed]

77. Blazar, B.R.; Kwon, B.S.; Panoskaltsis-Mortari, A.; Kwak, K.B.; Peschon, J.J.; Taylor, P.A. Ligation of 4-1BB (CDw137) regulates graft-versus-host disease, graft-versus-leukemia, and graft rejection in allogeneic bone marrow transplant recipients. J. Immunol. 2001, 166, 3174-3183. [CrossRef] [PubMed]

78. Blazar, B.R.; Levy, R.B.; Mak, T.W.; Panoskaltsis-Mortari, A.; Muta, H.; Jones, M.; Roskos, M.; Serody, J.S.; Yagita, H.; Podack, E.R.; et al. CD30/CD30 ligand (CD153) interaction regulates CD4+ T cell-mediated graft-versus-host disease. J. Immunol. 2004, 173, 2933-2941. [CrossRef] [PubMed]

79. Blazar, B.R.; Sharpe, A.H.; Chen, A.I.; Panoskaltsis-Mortari, A.; Lees, C.; Akiba, H.; Yagita, H.; Killeen, N.; Taylor, P.A. Ligation of OX40 (CD134) regulates graft-versus-host disease (GVHD) and graft rejection in allogeneic bone marrow transplant recipients. Blood 2003, 101, 3741-3748. [CrossRef] [PubMed]

80. Blazar, B.R.; Carreno, B.M.; Panoskaltsis-Mortari, A.; Carter, L.; Iwai, Y.; Yagita, H.; Nishimura, H.; Taylor, P.A. Blockade of programmed death-1 engagement accelerates graft-versus-host disease lethality by an IFN-gamma-dependent mechanism. J. Immunol. 2003, 171, 1272-1277. [CrossRef] [PubMed]

81. Wu, C.J.; Ritz, J. Induction of tumor immunity following allogeneic stem cell transplantation. Adv. Immunol. 2006, 90, 133-73. [PubMed]

82. Chen, B.J.; Cui, X.; Sempowski, G.D.; Liu, C.; Chao, N.J. Transfer of allogeneic CD62L-memory T cells without graft-versus-host disease. Blood 2004, 103, 1534-1541. [CrossRef] [PubMed]

83. Zhang, Y.; Joe, G.; Hexner, E.; Zhu, J.; Emerson, S.G.; Haferlach, T. Host-reactive CD8+ memory stem cells in graftversus-host disease. Nat. Med. 2005, 11, 1299-1305. [CrossRef] [PubMed]

84. Zhang, Y.; Joe, G.; Hexner, E.; Zhu, J.; Emerson, S.G. Alloreactive memory T cells are responsible for the persistence of graft-versus-host disease. J. Immunol. 2005, 174, 3051-3058. [CrossRef] [PubMed]

85. Zheng, H.; Matte-Martone, C.; Li, H.; Anderson, B.E.; Venketesan, S.; Sheng Tan, H.; Jain, D.; McNiff, J.; Shlomchik, W.D. Effector memory CD4+ T cells mediate graft-versus-leukemia without inducing graft-versus-host disease. Blood 2008, 111, 2476-2484. [CrossRef] [PubMed]

86. Anderson, B.E.; McNiff, J.; Yan, J.; Doyle, H.; Mamula, M.; Shlomchik, M.J.; Shlomchik, W.D. Memory CD4+ T cells do not induce graft-versus-host disease. J. Clin. Investig. 2003, 112, 101-108. [CrossRef] [PubMed]

87. Liu, E.H.; Siegel, R.M.; Harlan, D.M.; O'Shea, J.J. T cell-directed therapies: Lessons learned and future prospects. Nat. Immunol. 2007, 8, 25-30. [CrossRef] [PubMed]

88. Yang, Y.G.; Qi, J.; Wang, M.G.; Sykes, M. Donor-derived interferon gamma separates graft-versus-leukemia effects and graft-versus-host disease induced by donor CD8 T cells. Blood 2002, 99, 4207-4215. [CrossRef] [PubMed]

89. Pan, L.; Delmonte, J., Jr; Jalonen, C.K.; Ferrara, J.L. Pretreatment of donor mice with granulocyte colony-stimulating factor polarizes donor T lymphocytes toward type-2 cytokine production and reduces severity of experimental graft-versus-host disease. Blood 1995, 86, 4422-4429. [PubMed]

90. Reddy, P.; Teshima, T.; Hildebrandt, G.; Williams, D.L.; Liu, C.; Cooke, K.R.; Ferrara, J.L. Pretreatment of donors with interleukin-18 attenuates acute graft-versus-host disease via STAT6 and preserves graft-versus-leukemia effects. Blood 2003, 101, 2877-2885. [CrossRef] [PubMed]

91. Fowler, D.H.; Kurasawa, K.; Smith, R.; Eckhaus, M.A.; Gress, R.E. Donor CD4-enriched cells of Th2 cytokine phenotype regulate graft-versus-host disease without impairing allogeneic engraftment in sublethally irradiated mice. Blood 1994, 84, 3540-3549. [PubMed] 
92. Kappel, L.W.; Goldberg, G.L.; King, C.G.; Suh, D.Y.; Smith, O.M.; Ligh, C.; Holland, A.M.; Grubin, J.; Mark, N.M.; Liu, C.; et al. IL-17 contributes to CD4-mediated graft-versus-host disease. Blood 2009, 113, 945-952. [CrossRef] [PubMed]

93. Yi, T.; Zhao, D.; Lin, C.L.; Zhang, C.; Chen, Y.; Todorov, I.; LeBon, T.; Kandeel, F.; Forman, S.; Zeng, D. Absence of donor Th17 leads to augmented Th1 differentiation and exacerbated acute graft-versus-host disease. Blood 2008, 112, 2101-2110. [CrossRef] [PubMed]

94. Cohen, J.L.; Trenado, A.; Vasey, D.; Klatzmann, D.; Salomon, B.L. CD4(+)CD25(+) immunoregulatory T Cells: New therapeutics for graft-versus-host disease. J. Exp. Med. 2002, 196, 401-406. [CrossRef] [PubMed]

95. Edinger, M.; Hoffmann, P.; Ermann, J.; Drago, K.; Fathman, C.G.; Strober, S.; Negrin, R.S. CD4+CD25+ regulatory $\mathrm{T}$ cells preserve graft-versus-tumor activity while inhibiting graft-versus-host disease after bone marrow transplantation. Nat. Med. 2003, 9, 1144-1150. [CrossRef] [PubMed]

96. Coghill, J.M.; Carlson, M.J.; Moran, T.P.; Serody, J.S. The biology and therapeutic potential of natural regulatory T-cells in the bone marrow transplant setting. Leuk. Lymphoma 2008, 49, 1860-1869. [CrossRef] [PubMed]

97. Nishimori, H.; Maeda, Y.; Teshima, T.; Sugiyama, H.; Kobayashi, K.; Yamasuji, Y.; Kadohisa, S.; Uryu, H.; Takeuchi, K.; Tanaka, T.; et al. Synthetic retinoid Am80 ameliorates chronic graft-versus-host disease by down-regulating Th1 and Th17. Blood 2012, 119, 285-295. [CrossRef] [PubMed]

98. Nishimori, H.; Maeda, Y.; Tanimoto, M. Chronic graft-versus-host disease: Disease biology and novel therapeutic strategies. Acta Med. Okayama 2013, 67, 1-8. [PubMed]

99. Wolff, D.; Gerbitz, A.; Ayuk, F.; Kiani, A.; Hildebrandt, G.C.; Vogelsang, G.B.; Elad, S.; Lawitschka, A.; Socie, G.; Pavletic, S.Z.; et al. Consensus conference on clinical practice in chronic graft-versus-host disease (GVHD): First-line and topical treatment of chronic GVHD. Biol. Blood Marrow Transplant. 2010, 16, 1611-1628. [CrossRef] [PubMed]

100. Fujiwara, H.; Maeda, Y.; Kobayashi, K.; Nishimori, H.; Matsuoka, K.; Fujii, N.; Kondo, E.; Tanaka, T.; Chen, L.; Azuma, M.; et al. Programmed death-1 pathway in host tissues ameliorates Th17/Th1-mediated experimental chronic graft-versus-host disease. J. Immunol. 2014, 193, 2565-2573. [CrossRef] [PubMed]

101. Dhir, S.; Slatter, M.; Skinner, R. Recent advances in the management of graft-versus-host disease. Arch. Dis. Child. 2014, 99, 1150-1157. [CrossRef] [PubMed]

102. Ruutu, T.; Gratwohl, A.; de Witte, T.; Afanasyev, B.; Apperley, J.; Bacigalupo, A.; Dazzi, F.; Dreger, P.; Duarte, R.; Finke, J.; et al. Prophylaxis and treatment of GVHD: EBMT-ELN working group recommendations for a standardized practice. Bone Marrow Transplant. 2014, 49, 168-173. [CrossRef] [PubMed]

103. Alyea, E.P.; Kim, H.T.; Ho, V.; Cutler, C.; DeAngelo, D.J.; Stone, R.; Ritz, J.; Antin, J.H.; Soiffer, R.J. Impact of conditioning regimen intensity on outcome of allogeneic hematopoietic cell transplantation for advanced acute myelogenous leukemia and myelodysplastic syndrome. Biol. Blood Marrow Transplant. 2006, 12, 1047-1055. [CrossRef] [PubMed]

104. Scott, B.L.; Sandmaier, B.M.; Storer, B.; Maris, M.B.; Sorror, M.L.; Maloney, D.G.; Chauncey, T.R.; Storb, R.; Deeg, H.J. Myeloablative vs nonmyeloablative allogeneic transplantation for patients with myelodysplastic syndrome or acute myelogenous leukemia with multilineage dysplasia: A retrospective analysis. Leukemia 2006, 20, 128-135. [CrossRef] [PubMed]

105. Storb, R.; Deeg, H.J.; Farewell, V.; Doney, K.; Appelbaum, F.; Beatty, P.; Bensinger, W.; Buckner, C.D.; Clift, R.; Hansen, J.; et al. Marrow transplantation for severe aplastic anemia: Methotrexate alone compared with a combination of methotrexate and cyclosporine for prevention of acute graft-versus-host disease. Blood 1986, 68, 119-125. [PubMed]

106. Storb, R.; Thomas, E.D.; Buckner, C.D.; Clift, R.A.; Johnson, F.L.; Fefer, A.; Glucksberg, H.; Giblett, E.R.; Lerner, K.G.; Neiman, P. Allogeneic marrow grafting for treatment of aplastic anemia. Blood 1974, 43, 157-180. [PubMed]

107. Powles, R.L.; Clink, H.M.; Spence, D.; Morgenstern, G.; Watson, J.G.; Selby, P.J.; Woods, M.; Barrett, A.; Jameson, B.; Sloane, J.; et al. Cyclosporin A to prevent graft-versus-host disease in man after allogeneic bone-marrow transplantation. Lancet 1980, 1, 327-329. [CrossRef]

108. Fay, J.W.; Wingard, J.R.; Antin, J.H.; Collins, R.H.; Piñeiro, L.A.; Blazar, B.R.; Saral, R.; Bierer, B.E.; Przepiorka, D.; Fitzsimmons, W.E.; et al. K506 (Tacrolimus) monotherapy for prevention of graft-versus-host disease after histocompatible sibling allogenic bone marrow transplantation. Blood 1996, 87, 3514-3519. [PubMed] 
109. Chao, N.J.; Chen, B.J. Prophylaxis and treatment of acute graft-versus-host disease. Semin. Hematol. 2006, 43, 32-41. [CrossRef] [PubMed]

110. Quellmann, S.; Schwarzer, G.; Hübel, K.; Greb, A.; Engert, A.; Bohlius, J. Corticosteroids for preventing graft-versus-host disease after allogeneic myeloablative stem cell transplantation. Cochrane Database Syst. Rev. 2008, 16, CD004885.

111. Kumar, S.; Chen, M.G.; Gastineau, D.A.; Gertz, M.A.; Inwards, D.J.; Lacy, M.Q.; Tefferi, A.; Harmsen, W.S.; Litzow, M.R. Prophylaxis of graft-versus-host disease with cyclosporine-prednisone is associated with increased risk of chronic graft-versus-host disease. Bone Marrow Transplant. 2001, 27, 1133-1140. [CrossRef] [PubMed]

112. Kanakry, C.G.; Tsai, H.L.; Bolaños-Meade, J.; Smith, B.D.; Gojo, I.; Kanakry, J.A.; Kasamon, Y.L.; Gladstone, D.E.; Matsui, W.; Borrello, I.; et al. Single-agent GVHD prophylaxis with posttransplantation cyclophosphamide after myeloablative, HLA-matched BMT for AML, ALL, and MDS. Blood 2014, 124, 3817-3827. [CrossRef] [PubMed]

113. Koreth, J.; Antin, J.H. Current and future approaches for control of graft-versus-host disease. Expert Rev. Hematol. 2008, 1, 111. [CrossRef] [PubMed]

114. Nash, R.A.; Johnston, L.; Parker, P.; McCune, J.S.; Storer, B.; Slattery, J.T.; Furlong, T.; Anasetti, C.; Appelbaum, F.R.; Lloid, M.E.; et al. A phase I/II study of mycophenolate mofetil in combination with cyclosporine for prophylaxis of acute graft-versus-host disease after myeloablative conditioning and allogeneic hematopoietic cell transplantation. Biol. Blood Marrow Transplant. 2005, 11, 495-505. [CrossRef] [PubMed]

115. Neumann, F.; Graef, T.; Tapprich, C.; Vaupel, M.; Steidl, U.; Germing, U.; Fenk, R.; Hinke, A.; Haas, R.; Kobbe, G. Cyclosporine A and mycophenolate mofetil vs cyclosporine A and methotrexate for graft-versus-host disease prophylaxis after stem cell transplantation from HLA-identical siblings. Bone Marrow Transplant. 2005, 35, 1089-1093. [CrossRef] [PubMed]

116. Reisner, Y.; Martelli, M.F. Bone marrow transplantation across HLA barriers by increasing the number of transplanted cells. Immunol. Today 1995, 16, 437-440. [CrossRef]

117. Ferrara, J.L.; Yanik, G. Acute graft versus host disease: Pathophysiology, risk factors, and prevention strategies. Clin. Adv. Hematol. Oncol. 2005, 3, 415-419. [PubMed]

118. Reisner, Y.; Itzicovitch, L.; Meshorer, A.; Sharon, N. Hemopoietic stem cell transplantation using mouse bone marrow and spleen cells fractionated by lectins. Proc. Natl. Acad. Sci. USA 1978, 75, 2933-2936. [CrossRef] [PubMed]

119. Reisner, Y.; Kapoor, N.; O’Reilly, R.J.; Good, R.A. Allogeneic bone marrow transplantation using stem cells fractionated by lectins: VI, in vitro analysis of human and monkey bone marrow cells fractionated by sheep red blood cells and soybean agglutinin. Lancet 1980, 2, 1320-1324. [CrossRef]

120. Reisner, Y.; Kapoor, N.; Kirkpatrick, D.; Pollack, M.S.; Dupont, B.; Good, R.A.; O’Reilly, R.J. Transplantation for acute leukaemia with HLA-A and B nonidentical parental marrow cells fractionated with soybean agglutinin and sheep red blood cells. Lancet 1981, 2, 327-331. [CrossRef]

121. Reisner, Y.; Kapoor, N.; Kirkpatrick, D.; Pollack, M.S.; Cunningham-Rundles, S.; Dupont, B.; Hodes, M.Z.; Good, R.A.; O'Reilly, R.J. Transplantation for severe combined immunodeficiency with HLA-A,B,D,DR incompatible parental marrow cells fractionated by soybean agglutinin and sheep red blood cells. Blood 1983, 61, 341-348. [PubMed]

122. Kernan, N.A.; Bordignon, C.; Keever, C.A.; Cunningham, I.; Castro-Malaspina, H.; Collins, N.H.; Small, T.N.; Brochstein, J.; Emanuel, D.; Laver, J.; et al. Graft failures after T cell depleted marrow transplants for leukemia: Clinical and in vitro characteristics. Transplant. Proc. 1989, 19 (Suppl. S7), 29-32.

123. Hanash, A.M.; Levy, R.B. Donor CD4+CD25+ T cells promote engraftment and tolerance following MHC-mismatched hematopoietic cell transplantation. Blood 2005, 105, 1828-1836. [CrossRef] [PubMed]

124. Aversa, F.; Tabilio, A.; Velardi, A.; Cunningham, I.; Terenzi, A.; Falzetti, F.; Ruggeri, L.; Barbabietola, G.; Aristei, C.; Latini, P.; et al. Treatment of high-risk acute leukemia with T-cell-depleted stem cells from related donors with one fully mismatched HLA haplotype. N. Engl. J. Med. 1998, 339, 1186. [CrossRef] [PubMed]

125. Bethge, W.A.; Faul, C.; Bornhäuser, M.; Stuhler, G.; Beelen, D.W.; Lang, P.; Stelljes, M.; Vogel, W.; Hägele, M.; Handgretinger, R.; et al. Haploidentical allogeneic hematopoietic cell transplantation in adults using CD3/CD19 depletion and reduced intensity conditioning: An update. Blood Cells Mol. Dis. 2008, 40, 13-19. [CrossRef] [PubMed] 
126. Bertaina, A.; Merli, P.; Rutella, S.; Pagliara, D.; Bernardo, M.E.; Masetti, R.; Pende, D.; Falco, M.; Handgretinger, R.; Moretta, F.; et al. HLA-haploidentical stem cell transplantation after removal of $\alpha \beta+$ $\mathrm{T}$ and $\mathrm{B}$ cells in children with nonmalignant disorders. Blood 2014, 124, 822-826. [CrossRef] [PubMed]

127. Wagner, J.E.; Thompson, J.S.; Carter, S.L.; Kernan, N.A. Effect of graft-versus-host disease prophylaxis on 3-year disease-free survival in recipients of unrelated donor bone marrow (T-cell Depletion Trial): A multi-centre, randomised phase II-III trial. Lancet 2005, 366, 733-741. [CrossRef]

128. Chakrabarti, S.; Hale, G.; Waldmann, H. Alemtuzumab (Campath-1H) in allogeneic stem cell transplantation: Where do we go from here? Transplant. Proc. 2004, 36, 1225-1227. [CrossRef] [PubMed]

129. Kanda, J.; Lopez, R.D.; Rizzieri, D.A. Alemtuzumab for the prevention and treatment of graft-versus-host disease. Int. J. Hematol. 2011, 93, 586-593. [CrossRef] [PubMed]

130. Martin, P.J.; Rowley, S.D.; Anasetti, C.; Chauncey, T.R.; Gooley, T.; Petersdorf, E.W.; van Burik, J.A.; Flowers, M.E.; Storb, R.; Appelbaum, F.R.; et al. A phase I-II clinical trial to evaluate removal of CD4 cells and partial depletion of CD8 cells from donor marrow for HLA-mismatched unrelated recipients. Blood 1999, 94, 192-199.

131. Ho, V.T.; Kim, H.T.; Li, S.; Hochberg, E.P.; Cutler, C.; Lee, S.J.; Fisher, D.C.; Milford, E.; Kao, G.; Daley, H.; et al . Partial CD8+ T-cell depletion of allogeneic peripheral blood stem cell transplantation is insufficient to prevent graft-versus-host disease. Bone Marrow Transplant. 2004, 34, 987-994. [CrossRef] [PubMed]

132. Ciceri, F.; Labopin, M.; Aversa, F.; Rowe, J.M.; Bunjes, D.; Lewalle, P.; Nagler, A.; Di Bartolomeo, P.; Lacerda, J.F.; Lupo Stanghellini, M.T.; et al. A survey of fully haploidentical hematopoietic stem cell transplantation in adults with high-risk acute leukemia: A risk factor analysis of outcomes for patients in remission at transplantation. Blood 2008, 112, 3574-3581. [CrossRef] [PubMed]

133. Tamari, R.; Chung, S.; Papadopoulos, E.B.; Jakubowski, A.A.; Hilden, P.; Devlin, S.M.; Goldberg, J.D.; Perales, M.A.; Ponce, D.M.; Sauter, C.S.; et al. CD34-Selected Hematopoietic Stem Cell Transplants Conditioned with Myeloablative Regimens and Antithymocyte Globulin for Advanced Myelodysplastic Syndrome: Limited Graft-versus-Host Disease without Increased Relapse. Biol. Blood Marrow Transplant. 2015, 21, 2106-2114. [CrossRef] [PubMed]

134. Greco, R.; Oliveira, G.; Stanghellini, M.T.; Vago, L.; Bondanza, A.; Peccatori, J.; Cieri, N.; Marktel, S.; Mastaglio, S.; Bordignon, C.; et al. Improving the safety of cell therapy with the TK-suicide gene. Front. Pharmacol. 2015, 5, 1-13. [CrossRef] [PubMed]

135. Martin, P.J.; Rizzo, J.D.; Wingard, J.R.; Ballen, K.; Curtin, P.T.; Cutler, C.; Litzow, M.R.; Nieto, Y.; Savani, B.N.; Schriber, J.R.; et al. First- and second-line systemic treatment of acute graft-versus-host disease: Recommendations of the American Society of Blood and Marrow Transplantation. Biol. Blood Marrow Transplant. 2012, 18, 1150-1163. [CrossRef] [PubMed]

136. Hockenbery, D.M.; Cruickshank, S.; Rodell, T.C.; Gooley, T.; Schuening, F.; Rowley, S.; David, D.; Brunvand, M.; Berryman, B.; Abhyankar, S.; et al. A randomized, placebo-controlled trial of oral beclomethasone dipropionate as a prednisone-sparing therapy for gastrointestinal graft-versus-host disease. Blood 2007, 109, 4557-4563. [CrossRef] [PubMed]

137. Noce, C.W.; Gomes, A.; Shcaira, V.; Corrêa, M.E.; Moreira, M.C.; Silva Júnior, A.; Gonçalves, L.S.; Garnica, M.; Maiolino, A.; Torres, S.R. Randomized double-blind clinical trial comparing clobetasol and dexamethasone for the topical treatment of symptomatic oral chronic graft-versus-host diseas. Biol. Blood Marrow Transplant. 2014, 20, 1163-1168. [CrossRef] [PubMed]

138. Baron, F.; Humblet-Baron, S.; Ehx, G.; Servais, S.; Hannon, M.; Belle, L.; Lechanteur, C.; Briquet, A.; Giet, O.; Baudoux, E.; et al. Thinking out of the box-new approaches to controlling GVHD. Curr. Hematol. Malig. Rep. 2014, 9, 73-84. [CrossRef] [PubMed]

139. Zeiser, R.; Burchert, A.; Lengerke, C.; Verbeek, M.; Maas-Bauer, K.; Metzelder, S.K.; Spoerl, S.; Ditschkowski, M.; Ecsedi, M.; Sockel, K.; et al. Ruxolitinib in corticosteroid-refractory graft-versus-host disease after allogeneic stem cell transplantation: A multicenter survey. Leukemia 2015, 29, 2062-2068. [CrossRef] [PubMed]

140. Spoerl, S.; Mathew, N.R.; Bscheider, M.; Schmitt-Graeff, A.; Chen, S.; Mueller, T.; Verbeek, M.; Fischer, J.; Otten, V.; Schmickl, M.; et al. Activity of therapeutic JAK 1/2 blockade in graft-versus-host disease. Blood 2014, 123, 3832-3842. [CrossRef] [PubMed]

141. Lee, S.J.; Flowers, M.E. Recognizing and managing chronic graft-versus-host disease. Hematol. Am. Soc. Hematol. Educ. Program. 2008, 134-141. [CrossRef] [PubMed] 
142. Pai, C.C.; Chen, M.; Mirsoian, A.; Grossenbacher, S.K.; Tellez, J.; Ames, E.; Sun, K.; Jagdeo, J.; Blazar, B.R.; Murphy, W.J.; et al. Treatment of chronic graft-versus-host disease with bortezomib. Blood 2014, 124, 1677-1688. [CrossRef] [PubMed]

143. Mulder, A.; Heidt, S.; Vergunst, M.; Roelen, D.L.; Claas, F.H. Proteasome inhibition profoundly affects activated human B cells. Transplantation 2013, 95, 1331-1337. [CrossRef] [PubMed]

144. Neubert, K.; Meister, S.; Moser, K.; Weisel, F.; Maseda, D.; Amann, K.; Wiethe, C.; Winkler, T.H.; Kalden, J.R.; Manz, R.A.; et al. The proteasome inhibitor bortezomib depletes plasma cells and protects mice with lupus-like disease from nephritis. Nat. Med. 2008, 17, 748-755. [CrossRef] [PubMed]

145. Kharfan-Dabaja, M.A.; Cutler, C.S. Rituximab for prevention and treatment of graft-versus-host disease. Int. J. Hematol. 2011, 93, 578-585. [CrossRef] [PubMed]

146. Lee, S.J.; Klein, J.P.; Barrett, A.J.; Ringden, O.; Antin, J.H.; Cahn, J.Y.; Carabasi, M.H.; Gale, R.P.; Giralt, S.; Hale, G.A.; et al. Severity of chronic graft-versus-host disease: Association with treatment-related mortality and relapse. Blood 2002, 100, 406-414. [CrossRef] [PubMed]

147. Khouri, I.F.; Saliba, R.M.; Giralt, S.A.; Lee, M.S.; Okoroji, G.J.; Hagemeister, F.B.; Korbling, M.; Younes, A.; Ippoliti, C.; Gajewski, J.L.; et al. Nonablative allogeneic hematopoietic transplantation as adoptive immunotherapy for indolent lymphoma: Low incidence of toxicity, acute graft-versus-host disease, and treatment-related mortality. Blood 2001, 98, 3593-3599. [CrossRef]

148. Khouri, I.F.; McLaughlin, P.; Saliba, R.M.; Hosing, C.; Korbling, M.; Lee, M.S.; Medeiros, L.J.; Fayad, L.; Samaniego, F.; Alousi, A.; et al. Eight-year experience with allogeneic stem cell transplantation for relapsed follicular lymphoma after nonmyeloablative conditioning with fludarabine, cyclophosphamide, and rituximab. Blood 2008, 111, 5530-5536. [CrossRef] [PubMed]

149. Stasi, R.; Cooper, N.; Del Poeta, G.; Stipa, E.; Laura Evangelista, M.; Abruzzese, E.; Amadori, S. Analysis of regulatory T-cell changes in patients with idiopathic thrombocytopenic purpura receiving $\mathrm{B}$ cell-depleting therapy with rituximab. Blood 2008, 112, 1147-1150. [CrossRef] [PubMed]

150. Springer, C.J.; Niculescu-Duvaz, I. Prodrug-activating systems in suicide gene therapy. J. Clin. Investig. 2000, 105, 1161-1167. [CrossRef] [PubMed]

151. Bondanza, A.; Valtolina, V.; Magnani, Z.; Ponzoni, M.; Fleischhauer, K.; Bonyhadi, M.; Traversari, C.; Sanvito, F.; Toma, S.; Radrizzani, M.; et al. Suicide gene therapy of graft-versus-host disease induced by central memory human T lymphocytes. Blood 2006, 107, 1828-1836. [CrossRef] [PubMed]

152. Mailly, L.; Leboeuf, C.; Tiberghien, P.; Baumert, T.; Robinet, E. Genetically engineered T-cells expressing a ganciclovir-sensitive HSV-tk suicide gene for the prevention of GvHD. Curr. Opin. Investig. Drugs 2010, 11, 559-570. [PubMed]

153. Lupo-Stanghellini, M.T.; Provasi, E.; Bondanza, A.; Ciceri, F.; Bordignon, C.; Bonini, C. Clinical impact of suicide gene therapy in allogeneic hematopoietic stem cell transplantation. Hum. Gene Ther. 2010, 21, 241-250. [CrossRef] [PubMed]

154. Zhou, X.; Di Stasi, A.; Tey, S.K.; Krance, R.A.; Martinez, C.; Leung, K.S.; Durett, A.G.; Wu, M.F.; Liu, H.; Leen, A.M.; et al. Long-term outcome after haploidentical stem cell transplant and infusion of $\mathrm{T}$ cells expressing the inducible caspase 9 safety transgene. Blood 2014, 123, 3895-3905. [CrossRef] [PubMed]

155. Sakaguchi, S.; Sakaguchi, N.; Asano, M.; Itoh, M.; Toda, M. Immunologic self-tolerance maintained by activated $\mathrm{T}$ cells expressing IL-2 receptor alpha-chains (CD25). Breakdown of a single mechanism of self-tolerance causes various autoimmune diseases. J. Immunol. 1995, 155, 1151-1164. [PubMed]

156. Taylor, P.A.; Lees, C.J.; Blazar, B.R. The infusion of ex vivo activated and expanded CD4(+)CD25(+) immune regulatory cells inhibits graft-versus-host disease lethality. Blood 2002, 99, 3493-3499. [CrossRef] [PubMed]

157. Taylor, P.A.; Panoskaltsis-Mortari, A.; Swedin, J.M.; Lucas, P.J.; Gress, R.E.; Levine, B.L.; June, C.H.; Serody, J.S.; Blazar, B.R. L-Selectin(hi) but not the L-selectin(lo) CD4+25+ T-regulatory cells are potent inhibitors of GVHD and BM graft rejection. Blood 2004, 104, 3804-3812. [CrossRef] [PubMed]

158. Joffre, O.; Gorsse, N.; Romagnoli, P.; Hudrisier, D.; van Meerwijk, J.P. Induction of antigen-specific tolerance to bone marrow allografts with CD4+CD25+ T lymphocytes. Blood 2004, 103, 4216-4221. [CrossRef] [PubMed]

159. Hoffmann, P.; Ermann, J.; Edinger, M.; Fathman, C.G.; Strober, S. Donor-type CD4(+)CD25(+) regulatory $\mathrm{T}$ cells suppress lethal acute graft-versus-host disease after allogeneic bone marrow transplantation. J. Exp. Med. 2002, 196, 389-399. [CrossRef] [PubMed]

160. Baecher-Allan, C.; Brown, J.A.; Freeman, G.J.; Hafler, D.A. CD4+CD25high regulatory cells in human peripheral blood. J. Immunol. 2001, 167, 1245-1253. [CrossRef] [PubMed] 
161. Rao, P.E.; Petrone, A.L.; Ponath, P.D. Differentiation and expansion of T cells with regulatory function from human peripheral lymphocytes by stimulation in the presence of TGF-\{beta\}. J. Immunol. 2005, 174, 14460-1455. [CrossRef]

162. Hori, S.; Nomura, T.; Sakaguchi, S. Control of regulatory T cell development by the transcription factor Foxp3. Science 2003, 299, 1057-1061. [CrossRef] [PubMed]

163. Allan, S.E.; Alstad, A.N.; Merindol, N.; Crellin, N.K.; Amendola, M.; Bacchetta, R.; Naldini, L.; Roncarolo, M.G.; Soudeyns, H.; Levings, M.K. Generation of potent and stable human CD4+ T regulatory cells by activation-independent expression of FOXP3. Mol. Ther. 2008, 16, 194-202. [CrossRef] [PubMed]

164. Cao, J.; Chen, C.; Zeng, L.; Li, L.; Li, Z.; Xu, K. Engineered regulatory T cells prevent graft-versus-host disease while sparing the graft-versus-leukemia effect after bone marrow transplantation. Leuk. Res. 2010, 34, 1374-1382. [CrossRef] [PubMed]

165. Kwon, B. Intervention with costimulatory pathways as a therapeutic approach for graft-versus-host disease. Exp. Mol. Med. 2010, 42, 675-683. [CrossRef] [PubMed]

166. Blazar, B.R.; Taylor, P.A.; Linsley, P.S.; Vallera, D.A. In vivo blockade of CD28/CTLA4: B7/BB1 interaction with CTLA4-Ig reduces lethal murine graft-versus-host disease across the major histocompatibility complex barrier in mice. Blood 1994, 83, 3815-3825. [PubMed]

167. Hakim, F.T.; Cepeda, R.; Gray, G.S.; June, C.H.; Abe, R. Acute graft-versus-host reaction can be aborted by blockade of costimulatory molecules. J. Immunol. 1995, 155, 1757-1766. [PubMed]

168. Yu, X.Z.; Martin, P.J.; Anasetti, C. Role of CD28 in acute graft-versus-host disease. Blood 1998, 92, $2963-2970$. [PubMed]

169. Sang, W.; Zhou, C.; Cheng, N.; Li, Z.; Zeng, L.; Xu, K. Control of mouse graft-versus-host disease following allogeneic bone marrow transplantation by blocking the CD28/B7 signaling pathway with lentiviral vector-mediated RNA interference. Immunol. Lett. 2011, 136, 194-202. [CrossRef] [PubMed]

170. Taylor, P.A.; Panoskaltsis-Mortari, A.; Freeman, G.J.; Sharpe, A.H.; Noelle, R.J.; Rudensky, A.Y.; Mak, T.W.; Serody, J.S.; Blazar, B.R. Targeting of inducible costimulator (ICOS) expressed on alloreactive T cells down-regulates graft-versus-host disease (GVHD) and facilitates engraftment of allogeneic bone marrow (BM). Blood 2005, 105, 3372-3380. [CrossRef] [PubMed]

171. Hubbard, V.M.; Eng, J.M.; Ramirez-Montagut, T.; Tjoe, K.H.; Muriglan, S.J.; Kochman, A.A.; Terwey, T.H.; Willis, L.M.; Schiro, R.; Heller, G.; et al. R. Absence of inducible costimulator on alloreactive T cells reduces graft versus host disease and induces Th2 deviation. Blood 2005, 106, 3285-3292. [CrossRef] [PubMed]

172. Saha, A.; Aoyama, K.; Taylor, P.A.; Koehn, B.H.; Veenstra, R.G.; Panoskaltsis-Mortari, A.; Munn, D.H.; Murphy, W.J.; Azuma, M.; Yagita, H.; et al. Host programmed death ligand 1 is dominant over programmed death ligand 2 expression in regulating graft-versus-host disease lethality. Blood 2013, 122, 3062-3073. [CrossRef] [PubMed]

173. Kitazawa, Y.; Fujino, M.; Wang, Q.; Kimura, H.; Azuma, M.; Kubo, M.; Abe, R.; Li, X.K. Involvement of the programmed death-1/programmed death-1 ligand pathway in CD4+CD25+ regulatory T-cell activity to suppress alloimmune responses. Transplantation 2007, 83, 774-782. [CrossRef] [PubMed]

174. Durie, F.H.; Aruffo, A.; Ledbetter, J.; Crassi, K.M.; Green, W.R.; Fast, L.D.; Noelle, R.J. Antibody to the ligand of CD40, gp39, blocks the occurrence of the acute and chronic forms of graft-vs-host disease. J. Clin. Investig. 1994, 94, 1333-1118. [CrossRef] [PubMed]

175. Blazar, B.R.; Taylor, P.A.; Panoskaltsis-Mortari, A.; Buhlman, J.; Xu, J.; Flavell, R.A.; Korngold, R.; Noelle, R.; Vallera, D.A. Blockade of CD40 ligand-CD40 interaction impairs CD4+ T cell-mediated alloreactivity by inhibiting mature donor $\mathrm{T}$ cell expansion and function after bone marrow transplantation. J. Immunol. 1997, 158, 29-39. [PubMed]

176. Buhlmann, J.E.; Gonzalez, M.; Ginther, B.; Panoskaltsis-Mortari, A.; Blazar, B.R.; Greiner, D.L.; Rossini, A.A.; Flavell, R.; Noelle, R.J. Cutting edge: Sustained expansion of CD8+ T cells requires CD154 expression by Th cells in acute graft versus host disease. J. Immunol. 1999, 162, 4373-4376. [PubMed]

177. Tamada, K.; Tamura, H.; Flies, D.; Fu, Y.X.; Celis, E.; Pease, L.R.; Blazar, B.R.; Chen, L. Blockade of LIGHT/LTbeta and CD40 signaling induces allospecific T cell anergy, preventing graft-versus-host disease. J. Clin. Investig. 2002, 109, 549-557. [CrossRef] [PubMed]

178. MacDonald, K.P.; Shlomchik, W.D.; Reddy, P. Biology of graft-versus-host responses: Recent insights. Biol. Blood Marrow Transplant. 2013, 19, S10-S14. [CrossRef] [PubMed] 
179. Choi, S.; Reddy, P. HDAC inhibition and graft versus host disease. Mol. Med. 2011, 17, 404-416. [CrossRef] [PubMed]

180. Reddy, P.; Sun, Y.; Toubai, T.; Duran-Struuck, R.; Clouthier, S.G.; Weisiger, E.; Maeda, Y.; Tawara, I.; Krijanovski, O.; Gatza, E.; et al. Histone deacetylase inhibition modulates indoleamine 2,3-dioxygenasedependent DC functions and regulates experimental graft-versus-host disease in mice. J. Clin. Investig. 2008, 118, 2562-2573. [CrossRef] [PubMed]

181. He, S.; Wang, J.; Kato, K.; Xie, F.; Varambally, S.; Mineishi, S.; Kuick, R.; Mochizuki, K.; Liu, Y.; Nieves, E.; et al. Inhibition of histone methylation arrests ongoing graft-versus-host disease in mice by selectively inducing apoptosis of alloreactive effector T cells. Blood 2012, 119, 1274-1282. [CrossRef] [PubMed]

182. Choi, J.; Ritchey, J.; Prior, J.L.; Holt, M.; Shannon, W.D.; Deych, E.; Piwnica-Worms, D.R.; DiPersio, J.F. In vivo administration of hypomethylating agents mitigate graft-versus-host disease without sacrificing graft-versus-leukemia. Blood 2010, 116, 129-139. [CrossRef] [PubMed]

183. Ebens, C.L.; Maillard, I. Notch signaling in hematopoietic cell transplantation and T cell alloimmunity. Blood Rev. 2013, 27, 269-277. [CrossRef] [PubMed]

184. Zhang, Y.; Sandy, A.R.; Wang, J.R.V.; Shan, G.T.; Tran, I.T.; Friedman, A.; Kato, K.; He, S.; Cui, S.; Hexner, E.; et al. Notch signaling is a critical regulator of allogeneic CD4+ T-cell responses mediating graft-versus-host disease. Blood 2011, 117, 299-308. [CrossRef] [PubMed]

185. Gatza, E.; Wahl, D.R.; Opipari, A.W.; Sundberg, T.B.; Reddy, P.; Liu, C.; Glick, G.D.; Ferrara, J.L. Manipulating the bioenergetics of alloreactive $\mathrm{T}$ cells causes their selective apoptosis and arrests graft-versus-host disease. Sci. Transl. Med. 2011, 3, 67ra8. [CrossRef] [PubMed]

186. Sun, K.; Welniak, L.A.; Panoskaltsis-Mortari, A.; O'Shaughnessy, M.J.; Liu, H.; Barao, I.; Riordan, W.; Sitcheran, R.; Wysocki, C.; Serody, J.S.; et al. Inhibition of acute graft-versus-host disease with retention of graft-versus-tumor effects by the proteasome inhibitor bortezomib. Proc. Natl. Acad. Sci. USA 2004, 101, 8120-8125. [CrossRef] [PubMed]

187. Sun, K.; Wilkins, D.E.; Anver, M.R.; Sayers, T.J.; Panoskaltsis-Mortari, A.; Blazar, B.R.; Welniak, L.A.; Murphy, W.J. Differential effects of proteasome inhibition by bortezomib on murine acute graft-versus-host disease (GVHD): Delayed administration of bortezomib results in increased GVHD-dependent gastrointestinal toxicity. Blood 2005, 106, 3293-3299. [CrossRef] [PubMed]

188. Valenzuela, J.O.; Iclozan, C.; Hossain, M.S.; Prlic, M.; Hopewell, E.; Bronk, C.C.; Wang, J.; Celis, E.; Engelman, R.W.; Blazar, B.R.; et al. PKCtheta is required for alloreactivity and GVHD but not for immune responses toward leukemia and infection in mice. J. Clin. Investig. 2009, 119, 3774-3786. [CrossRef] [PubMed]

189. Berg-Brown, N.N.; Gronski, M.A.; Jones, R.G.; Elford, A.R.; Deenick, E.K.; Odermatt, B.; Littman, D.R.; Ohashi, P.S. PKCtheta signals activation versus tolerance in vivo. J. Exp. Med. 2004, 199, 743-752. [CrossRef] [PubMed]

190. Gruber, T.; Hermann-Kleiter, N.; Pfeifhofer-Obermair, C.; Lutz-Nicoladoni, C.; Thuille, N.; Letschka, T.; Barsig, J.; Baudler, M.; Li, J.; Metzler, B.; et al. PKC theta cooperates with PKC alpha in alloimmune responses of T cells in vivo. Mol. Immunol. 2009, 46, 2071-2079. [CrossRef] [PubMed]

191. Haarberg, K.M.; Li, J.; Heinrichs, J.; Wang, D.; Liu, C.; Bronk, C.C.; Kaosaard, K.; Owyang, A.M.; Holland, S.; Masuda, E.; et al. Pharmacologic inhibition of PKC $\alpha$ and PKC $\theta$ prevents GVHD while preserving GVL activity in mice. Blood 2013, 122, 2500-2511. [CrossRef] [PubMed]

192. O'Connell, R.M.; Rao, D.S.; Chaudhuri, A.A.; Baltimore, D. Physiological and pathological roles for microRNAs in the immune system. Nat. Rev. Immunol. 2010, 10, 111-122. [CrossRef] [PubMed]

193. Ranganathan, P.; Heaphy, C.E.; Costinean, S.; Stauffer, N.; Na, C.; Hamadani, M.; Santhanam, R.; Mao, C.; Taylor, P.A.; Sandhu, S.; et al. Regulation of acute graft-versus-host disease by microRNA-155. Blood 2012, 119, 4786-4797. [CrossRef] [PubMed]

194. Ma, H.H.; Ziegler, J.; Li, C.; Sepulveda, A.; Bedeir, A.; Grandis, J.; Lentzsch, S.; Mapara, M.Y. Sequential activation of inflammatory signaling pathways during graft-versus-host disease (GVHD): Early role for STAT1 and STAT3. Cell Immunol. 2011, 268, 37-46. [CrossRef] [PubMed]

195. Ma, H.; Lu, C.; Ziegler, J.; Liu, A.; Sepulveda, A.; Okada, H.; Lentzsch, S.; Mapara, M.Y. Absence of Stat1 in donor CD $4 \mathrm{~T}$ cells promotes the expansion of Tregs and reduces graft-versus-host disease in mice. J. Clin. Investig. 2011, 121, 2554-2569. [CrossRef] [PubMed] 
196. Laurence, A.; Amarnath, S.; Mariotti, J.; Kim, Y.C.; Foley, J.; Eckhaus, M.; O'Shea, J.J.; Fowler, D.H. STAT3 transcription factor promotes instability of nTreg cells and limits generation of iTreg cells during acute murine graft-versus-host disease. Immunity 2012, 37, 209-222. [CrossRef] [PubMed]

197. Cetkovic-Cvrlje, M.; Roers, B.A.; Schonhoff, D.; Waurzyniak, B.; Liu, X.P.; Uckun, F.M. Treatment of post-bone marrow transplant acute graft-versus-host disease with a rationally designed JAK3 inhibitor. Leuk. Lymphoma 2002, 43, 1447-1453. [CrossRef] [PubMed]

198. Uckun, F.M.; Roers, B.A.; Waurzyniak, B.; Liu, X.P.; Cetkovic-Cvrlje, M. Janus kinase 3 inhibitor WHI-P131/JANEX-1 prevents graft-versus-host disease but spares the graft-versus-leukemia function of the bone marrow allografts in a murine bone marrow transplantation model. Blood 2002, 99, 4192-4199. [CrossRef] [PubMed]

199. Stanford, M.M.; McFadden, G. Myxoma virus and oncolytic virotherapy: A new biologic weapon in the war against cancer. Expert Opin. Biol. Ther. 2007, 7, 1415-1225. [CrossRef] [PubMed]

200. Russell, S.J.; Peng, K.W.; Bell, J.C. Oncolytic virotherapy. Nat. Biotechnol. 2012, 30, 658-670. [CrossRef] [PubMed]

201. Kerr, P.J. Myxomatosis in Australia and Europe: A model for emerging infectious diseases. Antivir. Res. 2012, 93, 387-415. [CrossRef] [PubMed]

202. Stanford, M.M.; Werden, S.J.; McFadden, G. Myxoma virus in the European rabbit: Interactions between the virus and its susceptible host. Vet. Res. 2007, 38, 299-318. [CrossRef] [PubMed]

203. Fenner, F. Adventures with poxviruses of vertebrates. FEMS Microbiol. Rev. 2000, 24, 123-133. [CrossRef] [PubMed]

204. Villa, N.Y.; Bais, S.; Chan, W.M.; Meacham, A.M.; Wise, E.; Rahman, M.M.; Moreb, J.S.; Rosenau, E.H.; Wingard, J.R.; McFadden, G.; et al. Ex vivo virotherapy with myxoma virus does not impair hematopoietic stem and progenitor cells. Cytotherapy 2016, 18, 465-480. [CrossRef] [PubMed]

205. Bartee, E.; McFadden, G. Human cancer cells have specifically lost the ability to induce the synergistic state caused by tumor necrosis factor plus interferon-beta. Cytokine 2009, 47, 199-205. [CrossRef] [PubMed]

206. Bartee, E.; Mohamed, M.R.; Lopez, M.C.; Baker, H.V.; McFadden, G. The addition of tumor necrosis factor plus beta interferon induces a novel synergistic antiviral state against poxviruses in primary human fibroblasts. J. Virol. 2009, 83, 498-511. [CrossRef] [PubMed]

207. Wang, G.; Barrett, J.W.; Stanford, M.; Werden, S.J.; Johnston, J.B.; Gao, X.; Sun, M.; Cheng, J.Q.; McFadden, G. Infection of human cancer cells with myxoma virus requires Akt activation via interaction with a viral ankyrin-repeat host range factor. Proc. Natl. Acad. Sci. USA 2006, 103, 4640-4645. [CrossRef] [PubMed]

208. Werden, S.J.; McFadden, G. Pharmacological manipulation of the akt signaling pathway regulates myxoma virus replication and tropism in human cancer cells. J. Virol. 2010, 84, 3287-3302. [CrossRef] [PubMed]

209. Rahman, M.M.; Liu, J.; Chan, W.M.; Rothenburg, S.; McFadden, G. Myxoma virus protein M029 is a dual function immunomodulator that inhibits PKR and also conscripts RHA/DHX9 to promote expanded host tropism and viral replication. PLoS Pathog. 2013, 9, e1003465. [CrossRef] [PubMed]

210. Werden, S.J.; McFadden, G. The role of cell signaling in poxvirus tropism: The case of the M-T5 host range protein of myxoma virus. Biochim. Biophys. Acta 2008, 1784, 228-237. [CrossRef] [PubMed]

211. Kim, M.; Williamson, C.T.; Prudhomme, J.; Bebb, D.G.; Riabowol, K.; Lee, P.W.; Lees-Miller, S.P.; Mori, Y.; Rahman, M.M.; McFadden, G.; et al. The viral tropism of two distinct oncolytic viruses, reovirus and myxoma virus, is modulated by cellular tumor suppressor gene status. Oncogene 2010, 29, 3990-3996. [CrossRef] [PubMed]

212. Rahman, M.M.; Madlambayan, G.J.; Cogle, C.R.; McFadden, G. Oncolytic viral purging of leukemic hematopoietic stem and progenitor cells with Myxoma virus. Cytokine Growth Factor Rev. 2010, 21, 169-175. [CrossRef] [PubMed]

213. Kim, M.; Madlambayan, G.J.; Rahman, M.M.; Smallwood, S.E.; Meacham, A.M.; Hosaka, K.; Scott, E.W.; Cogle, C.R.; McFadden, G. Myxoma virus targets primary human leukemic stem and progenitor cells while sparing normal hematopoietic stem and progenitor cells. Leukemia 2009, 23, 2313-2317. [CrossRef] [PubMed]

214. Chan, W.M.; Rahman, M.M.; McFadden, G. Oncolytic myxoma virus: The path to clinic. Vaccine 2013, 31, 4252-4258. [CrossRef] [PubMed] 